\title{
Long-term Impact of Sewage Sludge Application on Rhizobium leguminosarum biovar trifolii: An Evaluation Using Meta-Analysis
}

\author{
Alex Charlton, Ruben Sakrabani, ${ }^{*}$ Steve P. McGrath, and Colin D. Campbell
}

\begin{abstract}
The Long-Term Sludge Experiment (LTSE) began in 1994 at nine UK field sites as part of continuing research into the effects of sludge-borne heavy metals on soil fertility. The long-term effects of $\mathrm{Zn}, \mathrm{Cu}$, and $\mathrm{Cd}$ on the most probable numbers of cells (MPN) of Rhizobium leguminosarum biovar trifolii were monitored for $8 \mathrm{yr}$ in sludge-amended soils. To assess the statutory limits set by the UK Sludge (Use in Agriculture) Regulations, the experimental data were reviewed using statistical methods of meta-analysis. Previous LTSE studies have focused predominantly on statistical significance rather than effect size, whereas meta-analysis focuses on the magnitude and direction of an effect, i.e., the practical significance rather than its statistical significance. Results showed $\mathrm{Zn}$ to be the most toxic element causing an overall significant decrease in Rhizobium MPN of $-26.6 \%$ during the LTSE. The effect of $\mathrm{Cu}$ showed no significant effect on Rhizobium MPN at concentrations below the UK limits, although a $-5 \%$ decrease in Rhizobium MPN was observed in soils where total $\mathrm{Cu}$ ranged from 100 to $<135 \mathrm{mg} \mathrm{kg}^{-1}$. Overall, there was nothing to indicate that $\mathrm{Cd}$ had a significant effect on Rhizobium MPN below the current UK statutory limit. In summary, the UK statutory limit for $\mathrm{Zn}$ appears to be insufficient for protecting Rhizobium from $\mathrm{Zn}$ toxicity effects.
\end{abstract}

\section{Core Ideas}

- Meta-analysis provides effect size of $\mathrm{Cd}, \mathrm{Cu}$, and $\mathrm{Zn}$ in sludge on Rhizobium MPN in soils.

- Zn in sludge significantly decreased Rhizobium MPN in soil by $-26.6 \%$.

- Below UK limits, Cu in sludge decreased Rhizobium MPN in soil less than $5 \%$.

- Cd in sludge had no significant effect on Rhizobium MPN in soils.

Copyright $\odot$ American Society of Agronomy, Crop Science Society of America, and Soil Science Society of America. 5585 Guilford Rd., Madison, WI 53711 USA.

All rights reserved.

J. Environ. Qual.

doi:10.2134/jeq2015.12.0590

This is an open access article distributed under the terms of the CC BY license

(https://creativecommons.org/licenses/by/4.0/)

Supplemental material is available online for this article.

Received 2 Dec. 2015.

Accepted 11 Apr. 2016.

*Corresponding author (r.sakrabani@cranfield.ac.uk).
A PPLICATION OF SEWAGE SLUDGE to agricultural land is currently seen within the UK as the best practical environmental option for recycling this material (Department for Environment, Food and Rural Affairs, 2007; Gendebien et al., 1999, 2010; Water UK, 2010). Previous work (Berrow and Webber, 1972; Smith, 1996; Thornton et al., 2001) has shown that, due to the domestic and industrial sources of wastewater and the nature of wastewater treatment processes themselves, sewage sludge frequently contains concentrations of potentially toxic heavy metals that are significantly greater than the background concentrations found in soils. This is problematic because heavy metals are extremely persistent and can contaminate soils for decades (Alloway and Jackson, 1991; McGrath, 1987). Although the quality of sludge materials has improved in recent years due to declining metal content, there remains an understandable concern that increasing the quantities of sewage sludge used in agriculture could potentially lead to an accumulation of heavy metals within the environment and a long-term reduction in the quality of agricultural soils.

To prevent a potentially hazardous accumulation of heavy metals in sludge-amended soils, the UKSludge(Use In Agriculture) Regulations set statutory maximum limits (Table 1) for $\mathrm{Cd}, \mathrm{Cu}$, $\mathrm{Pb}, \mathrm{Hg}, \mathrm{Ni}$, and $\mathrm{Zn}$ because these are considered to pose the greatest risk to soil and human health (UK Statutory Instrument, 1989). Following implementation of the statutory limits, two independent scientific reviews were conducted to determine possible risks to food safety, assess the potential long-term impacts of repeated sludge application to agricultural land, and confirm that the legislation put in place was sufficient to protect soil quality. These were performed by the Steering Group on Chemical Aspects of Food Surveillance (Ministry of Agriculture, Fisheries and Food, 1993a) and an independent scientific committee (Ministry of Agriculture, Fisheries and Food, 1993b), both commissioned on behalf of the UK Ministry for Agriculture, Fisheries and Food and the UK Department of Environment (now combined as the Department for Environment, Food and Rural Affairs). Overall, it was concluded that heavy metal uptake by plants was unlikely to pose a significant risk to food safety (Ministry of Agriculture, Fisheries and Food, 1993a); hence the limits proposed by the

A. Charlton and R. Sakrabani, Cranfield Soil and Agrifood Institute, School of Water, Energy and Environment, Cranfield Univ., Cranfield, Bedfordshire MK43 OAL, UK; S. McGrath, Rothamsted Research, Harpenden, Herts AL5 2JQ, UK; C. Campbell, James Hutton Institute, Craigiebuckler, Aberdeen, Scotland, AB15 8QH, UK, and Dep. of Soil and Environment, Swedish Univ. of Agricultural Sciences, Uppsala SE750 07, Sweden. Assigned to Associate Editor James Ippolito.

Abbreviations: $\mathrm{CL}$, confidence limit; $\mathrm{LOEC}$, lowest observed effect concentration; LTSE, Long-Term Sludge Experiments; MPN, most probable numbers. 
Table 1. Maximum concentrations of heavy metals in sludge-amended soils and average annual rate of application during a 10-yr period permitted by the UK Sludge (Use In Agriculture) Regulations (UK Statutory Instrument, 1989).

\begin{tabular}{|c|c|c|c|c|c|}
\hline \multirow{2}{*}{ Metal } & \multicolumn{4}{|c|}{ Soil limit value } & \multirow{2}{*}{$\begin{array}{l}\text { Max. permissible } \\
\text { annual avg. over } 10 \mathrm{y}\end{array}$} \\
\hline & $\mathrm{pH} 5.0<5.5$ & $\mathrm{pH} 5.5<6.0$ & pH 6.0-7.0 & $\mathrm{pH}>7.0$ & \\
\hline & \multicolumn{4}{|c|}{$\longrightarrow \mathrm{mg} \mathrm{kg}^{-1} \longrightarrow$} & $\mathrm{kg} \mathrm{ha}^{-1} \mathrm{yr}^{-1}$ \\
\hline $\mathrm{Zn}$ & 200 & $250(200) \dagger$ & $300(200)$ & $450(300)$ & 15.0 \\
\hline $\mathrm{Cu}$ & 80 & 100 & 135 & 200 & 7.5 \\
\hline $\mathrm{Ni}$ & 50 & 60 & 75 & 110 & 3.0 \\
\hline \multicolumn{6}{|c|}{ pH 5.0 and above } \\
\hline$\overline{\mathrm{Cd}}$ & \multicolumn{4}{|c|}{3} & 0.15 \\
\hline $\mathrm{Pb}$ & \multicolumn{4}{|c|}{300} & 15.0 \\
\hline $\mathrm{Hg}$ & \multicolumn{4}{|c|}{1} & 0.1 \\
\hline
\end{tabular}

† Values in parentheses are UK advisory limits (Ministry of Agriculture, Fisheries and Food, 1993b).

UK Sludge (Use In Agriculture) Regulations were deemed sufficient to protect plants, animals, and humans from metal toxicity. However, this could not be said for soil microorganisms (Ministry of Agriculture, Fisheries and Food, 1993b).

Evidence for the potential impact of heavy metals on the soil microbial community was only beginning to emerge when the UK Sludge (Use In Agriculture) Regulations were first drafted, and therefore soil microorganisms were not considered when establishing the statutory limits. However, there was concern that a decrease in the diversity and activity of soil microorganisms due to heavy metal toxicity could disrupt biogeochemical processes essential to crop production (Ministry of Agriculture, Fisheries and Food, 1993b). The alarm was raised in 1984 when a marked decline in the health of white clover (Trifolium repens L.) growing on sludge-amended soils was observed at the Woburn Market Garden Experiment (Bedfordshire, UK). Investigations performed by McGrath et al. (1988) and Giller et al. (1989) subsequently confirmed that the observed decline in clover health was due to the ineffective fixation of atmospheric $\mathrm{N}_{2}$. This was caused by the toxic effect of heavy metals on Rhizobium leguminosarum biovar trifolii in soil and was not a direct phytotoxic effect on the clover itself, as plant health was restored by the addition of inorganic $\mathrm{N}$ fertilizer (McGrath et al., 1988). To elucidate which metals were having an effect on Rhizobium, Chaudri et al. (1992) added metal salt solutions ( $\mathrm{Cd}, \mathrm{Cu}, \mathrm{Ni}$, and $\mathrm{Zn}$ ), at six different rates, to soils previously amended with farmyard manure (i.e., with low metal content). After 18 months, no Rhizobium cells were found in soils treated with the $\mathrm{Zn}\left(\geq 385 \mathrm{mg} \mathrm{kg}^{-1}\right)$ and $\mathrm{Cd}$ $\left(\geq 7.1 \mathrm{mg} \mathrm{kg}^{-1}\right)$ salt solutions, with reductions of 82 and $99 \%$ also observed in soils containing concentrations of $\mathrm{Cu}$ at 191 and 225 $\mathrm{mg} \mathrm{kg}^{-1}$, respectively; $\mathrm{Ni}$ appeared to have no effect on Rhizobium across the concentration range of 26 to $54 \mathrm{mg} \mathrm{kg}^{-1}$.

To verify these results, Chaudri et al. (1993) performed an investigation at two long-term sludge experiment field sites in Brunswick (Lower Saxony, Germany). The number of Rhizobium cells (cells $\mathrm{g}^{-1}$ soil) found in arable and ex-woodland soils receiving inorganic fertilizers ranged from 4.2 to $9.3 \times$ $10^{3}$ and $9.3 \times 10^{3}$ to $4.0 \times 10^{4}$, respectively, with similar ranges seen in soils receiving a "low-metal" sludge treatment at a rate of $100 \mathrm{~m}^{3} \mathrm{ha}^{-1} \mathrm{yr}^{-1}$. At both sites, the number of Rhizobium cells in soils receiving $300 \mathrm{~m}^{3} \mathrm{ha}^{-1} \mathrm{yr}^{-1}$ of a "high-metal" sludge treatment decreased dramatically where the total concentration of Zn exceeded the UK statutory limits—reaching no observable cells in some cases. Most alarming, however, was the decline in Rhizobium cell numbers seen in the arable soil receiving $300 \mathrm{~m}^{3}$ $\mathrm{ha}^{-1} \mathrm{yr}^{-1}$ of the "low-metal" sludge treatment, eventually reaching zero cells as the total concentration of $\mathrm{Zn}$ increased from 218 to $254 \mathrm{mg} \mathrm{kg}^{-1}$. This decline occurred at concentrations below the UK statutory limit for $\mathrm{Zn}$, although it was noted that the corresponding limit set by Germany $\left(200 \mathrm{mg} \mathrm{Zn} \mathrm{kg}^{-1}\right.$ for soils with $\mathrm{pH}>6$ ) would prevent such an occurrence. These results were taken into account when reviewing the UK Sludge (Use In Agriculture) Regulations, prompting the recommendation that precautionary limits of 200 and $300 \mathrm{mg} \mathrm{Zn} \mathrm{kg}^{-1}$ should be applied to sludge-amended soils with $\mathrm{pH} 5$ to 7 and $\mathrm{pH}>7$, respectively (Ministry of Agriculture, Fisheries and Food, 1993b).

One of the major obstacles encountered when setting regulatory limits remains a lack of data available to establish doseresponse curves, giving more accurate estimates of the minimum heavy metal concentrations having an adverse effect on soil microorganisms. The long-term impacts of heavy metal contamination on soil microorganisms are still not fully understood (Giller et al., 1998, 1999, 2009), and the need for long-term monitoring of soil microbial communities in contaminated soils has been recognized by several researchers (McBride, 2003; McGrath et al., 1994, 1995). Therefore, following the review of the UK Sludge (Use In Agriculture) Regulations, an investigation into the longterm impact of sewage sludge applications on soil microorganisms was established by the Department for Environment, Food and Rural Affairs as part of continuing research into the effects of heavy metals on soil fertility (Ministry of Agriculture, Fisheries and Food, 1993b).

\section{Long-term Sludge Experiments}

The Long-Term Sludge Experiments (LTSE), conducted by ADAS, Rothamsted Research, and WRc in England and Wales and the Macaulay Land Use Research Institute (now the James Hutton Institute) and SAC (now SRUC) in Scotland, began in 1994 at nine UK field sites (Fig. 1), chosen to provide a range of soil properties (Table 2) from various climatic regions (UK Water Industry Research Limited, 2002, 2007; Gibbs et al., 2006). Five sludge treatments were applied annually to experimental plots during the course of 4 yr (1994-1997). Three of the sludge treatments contained elevated concentrations of either $\mathrm{Zn}, \mathrm{Cu}$, or $\mathrm{Cd}$ and were applied in increasing quantities to establish dose-response curves for the three heavy metals (Table 3). The remaining "uncontaminated" treatments contained concentrations of heavy metals typical for sludge produced in the UK (Control 1 and Control 2; Table 4) and were applied at a single rate (Table 2) to control for the effect of applying organic $\mathrm{C}$ to soil; an untreated soil was also included 


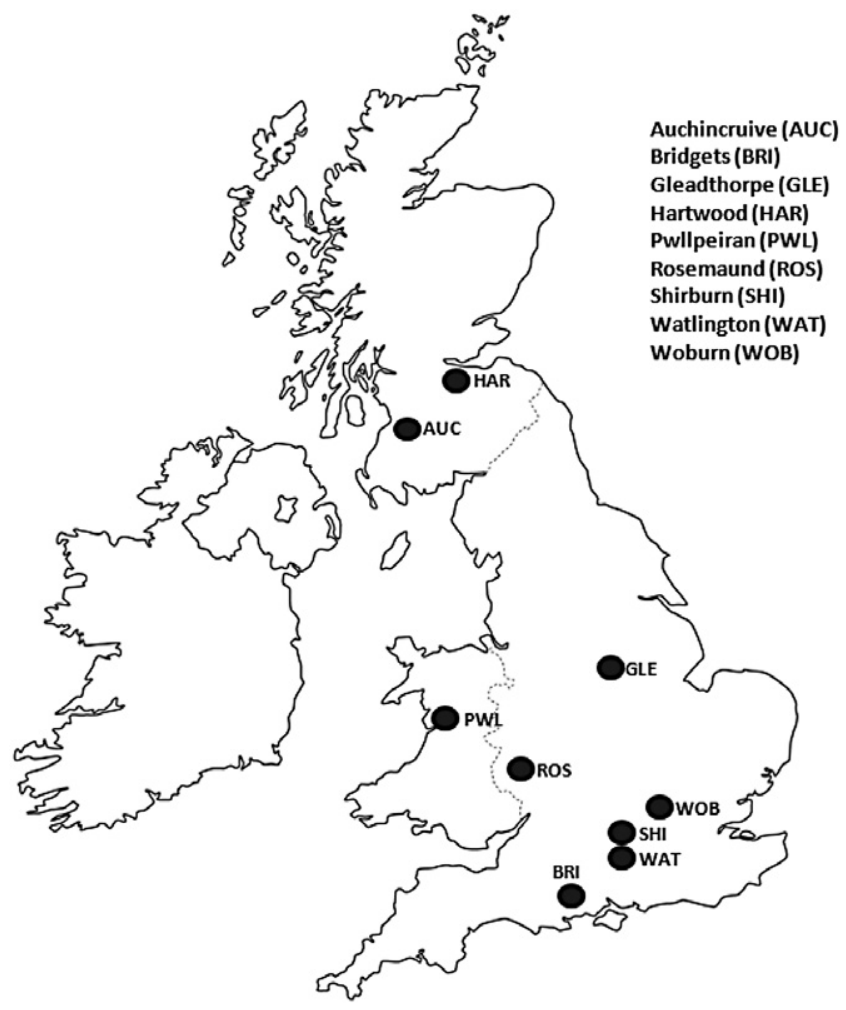

Fig. 1. Location of the Long-term Sludge Experiment field sites (adapted from Gibbs et al., 2006).

in the experimental design (the experimental design was described in detail by Gibbs et al. [2006] and UK Water Industry Research Limited [2002, 2007]). Application of the $\mathrm{Zn}, \mathrm{Cu}$, and $\mathrm{Cd}$ sludge treatments were supplemented with corresponding sludge material (i.e., digested [for $\mathrm{Zn}$ and $\mathrm{Cd}$ ] and undigested [for $\mathrm{Cu}$ ]; Table 4) from Controls 1 and 2 to ensure that uniform quantities of organic $\mathrm{C}$ were applied across all levels of the dose-response curves (Gibbs et al., 2006). Note that the rate of organic $C$ application for digested and undigested sludge treatments varied among sites (Table 2). The same sludge cake materials were transported to each site to ensure that exactly the same treatments were applied using the same methods of application. Sludge treatments were replicated three times $(n=3)$ in fully randomized blocks consisting of 6- by 8 -m plots and annually cultivated by spading machine to a depth of $25 \mathrm{~cm}$ (Gibbs et al., 2006). Each dose-response curve was comprised of four levels of increasing metal concentration, ranging from 150 to 450,50 to 200 , and 1 to $4 \mathrm{mg} \mathrm{kg}^{-1}$ for $\mathrm{Zn}, \mathrm{Cu}$, and Cd, respectively, although the target metal concentrations were not achieved at all of the sites (Table 5; Gibbs et al., 2006); an additional level was included for the Shirburn site due to the calcareous nature of the soil. Soil pH was kept constant at all sites for the duration of the experiment by the application of lime (with the exception of the calcareous site, Shirburn, which was left at the natural $\mathrm{pH}$ of 8). The sites in England and Wales were maintained at a $\mathrm{pH}$ of 6.5, whereas the soil $\mathrm{pH}$ at the Scottish sites, Auchincruive and Hartwood, were kept at 6.0 and 5.8 , respectively.

In 1997 the most probable numbers of cells (MPN) of Rhizobium ( $\log _{10}$ cells $\mathrm{g}^{-1}$ soil) observed in sludge-amended soils were slightly lower than in the untreated soil, with the exception of the Auchincruive site (Gibbs et al., 2006). Furthermore, at the Watlington field site, the reduction in Rhizobium MPN in soil receiving the $\mathrm{Zn}$ sludge treatment at Dose-Response Level 3 (where concentrations of $\mathrm{Zn}$ were closest to the UK statutory limit) was $>1 \log _{10}$ cells $\mathrm{g}^{-1}$ soil compared with the corresponding uncontaminated control (Control 1); however, the difference was not found to be statistically significant (Chaudri et al., 2008). Therefore, it was concluded that there was insufficient evidence to indicate an adverse effect of heavy metals on Rhizobium MPN in the short term.

Following the final applications of sludge in 1997, Rhizobium cell numbers continued to be monitored for $8 \mathrm{yr}$, with sampling events occurring in 1999, 2001, 2003, and 2005 (Rhizobium MPN was not measured at Auchincruive in 1999). Statistical analysis of the experimental data for each of the sampling events was done by analysis of variance (ANOVA) and multiple regression to

Table 2. Soil properties at each of the Long-Term Sludge Experiment field sites in 1994 prior to the application of sludge treatments. Application rates for digested and undigested sludge treatments applied from 1994 to 1997 are also given (adapted from Gibbs et al. 2006).

\begin{tabular}{|c|c|c|c|c|c|c|c|c|c|}
\hline Property & Auchincruive & Bridgets & Gleadthorpe & Hartwood & Pwllpeiran & Rosemaund & Shirburn & Watlington & Woburn \\
\hline Sand, $\%$ & 51 & 10 & 71 & 59 & 24 & 8 & 44 & 56 & 80 \\
\hline Silt, \% & 29 & 60 & 22 & 20 & 53 & 67 & 36 & 28 & 12 \\
\hline Clay, \% & 20 & 30 & 7 & 21 & 23 & 25 & 20 & 16 & 8 \\
\hline Texture & $\begin{array}{l}\text { sandy clay } \\
\text { loam }\end{array}$ & silt clay loam & sandy loam & $\begin{array}{l}\text { sand clay } \\
\text { loam }\end{array}$ & $\begin{array}{l}\text { clay } \\
\text { loam }\end{array}$ & silt clay loam & $\begin{array}{l}\text { clay loam } \\
\text { (calcareous) }\end{array}$ & sandy loam & $\begin{array}{l}\text { loamy } \\
\text { sand }\end{array}$ \\
\hline $\mathrm{pH}$ & 6.0 & 6.8 & 7.1 & 5.8 & 5.4 & 7.0 & 8.0 & 7.4 & 7.2 \\
\hline Organic C, \% & 2.5 & 1.5 & 1.2 & 4.7 & 3.3 & 1.7 & 3.0 & 1.3 & 1.3 \\
\hline $\mathrm{Fe}_{2} \mathrm{O}_{3^{\prime}} \%$ & 4.24 & 4.00 & 1.66 & 3.32 & 5.69 & 4.77 & 3.25 & 3.71 & 2.90 \\
\hline $\mathrm{Al}_{2} \mathrm{O}_{3^{\prime}} \%$ & 3.54 & 5.10 & 1.51 & 7.87 & 4.97 & 5.77 & 2.45 & 2.25 & 1.13 \\
\hline $\mathrm{MnO}_{2^{\prime}} \%$ & 0.12 & 0.23 & 0.06 & 0.96 & 0.15 & 0.16 & 0.12 & 0.09 & 0.03 \\
\hline Total Zn, mg kg-1 & $82.4(0.42) \dagger$ & $49.4(0.61)$ & $34.4(0.92)$ & $72.3(1.87)$ & $140(4.59)$ & $77.8(0.98)$ & $68.5(0.94)$ & $43.3(0.49)$ & $44.8(1.06)$ \\
\hline Total Cu, mg kg-1 & $22.6(0.14)$ & $12.2(0.24)$ & $7.4(0.28)$ & $19.8(0.33)$ & $13.2(0.74)$ & $17.3(0.09)$ & $13.1(0.12)$ & $11.4(0.11)$ & $13.9(0.36)$ \\
\hline Total Cd, mg kg ${ }^{-1}$ & $0.33(<0.01)$ & $0.95(0.04)$ & $0.17(0.01)$ & $0.23(0.01)$ & $0.15(<0.01)$ & $0.24(0.01)$ & $0.37(0.01)$ & $0.27(0.01)$ & $0.12(<0.01)$ \\
\hline $\begin{array}{l}\text { Rhizobium MPN, } \\
\log _{10} \text { cells } \mathrm{g}^{-1} \text { soil }\end{array}$ & 4.6 & 4.8 & 4.9 & 4.8 & 2.8 & 5.0 & 4.6 & 4.9 & 4.7 \\
\hline $\begin{array}{l}\text { Digested sludge, } \\
\mathrm{tC} \mathrm{ha}^{-1} \mathrm{yr}^{-1}\end{array}$ & 17.25 & 12.00 & 17.25 & 18.50 & 8.25 & 14.25 & 9.25 & 15.75 & 20.25 \\
\hline $\begin{array}{l}\text { Undigested sludge, } \\
\mathrm{tC} \mathrm{ha}^{-1} \mathrm{yr}^{-1}\end{array}$ & 20.75 & 12.25 & 17.00 & 20.25 & 7.50 & 14.25 & 10.25 & 16.75 & 20.25 \\
\hline
\end{tabular}

† Values in parentheses are standard errors $(n=3)$.

Journal of Environmental Quality 
determine the effect of each metal on Rhizobium at each of the field sites. During 1999 and 2001, cell numbers generally remained lower in sludge-amended soils than the untreated soil. This was thought to be due to unfavorable competition from other proliferating microorganisms because the soil microbial biomass $\mathrm{C}$ content was greater in the sludge-amended soils than the untreated soil at each of the LTSE field sites (UK Water Industry Research Limited, 2002, 2007). A number of these decreases, observed at six of the LTSE field sites (Gleadthorpe, Hartwood, Rosemaund, Shirburn, and Watlington) in 1999, were found to be statistically significant $(p<0.05)$ in soils receiving the $\mathrm{Zn}, \mathrm{Cu}$, and $\mathrm{Cd}$ sludge treatments. By 2001, however, significant differences $(p<0.05)$ were observed only in soils receiving the $\mathrm{Zn}$ and $\mathrm{Cd}$ sludge treatments, indicating that the Rhizobium populations in soils receiving the $\mathrm{Cu}$ sludge treatment were recovering (UK Water Industry Research Limited, 2002). No statistically significant differences

Table 3. Target metal concentrations for dose-response curves at Long-Term Sludge Experiment sites.

\begin{tabular}{lccc}
\hline Dose-response & \multicolumn{3}{c}{ Target metal concentration in soil } \\
\cline { 2 - 4 } curve & Zn & Cu & Cd \\
\cline { 2 - 4 } Level 1 & 150 & 50 & 1 \\
Level 2 & 250 & 100 & 2 \\
Level 3 & 350 & 150 & 3 \\
Level 4 & 450 & 200 & 4 \\
Level 5† & 600 & 275 & 5 \\
\hline
\end{tabular}

† Additional level applied only at the Shirburn site to account for potential calcareous soil-metal interactions. in Rhizobium MPN between soils receiving contaminated and uncontaminated sludge treatments were reported for any of the nine field sites during 1999 or 2001 . However, significant inverse relationships were found between Rhizobium MPN and the total concentrations of $\mathrm{Zn}$ and $\mathrm{Cu}$ at five of the LTSE field sites in 1999 (UK Water Industry Research Limited, 2002; Table 6). In 2001, no significant relationships were observed between total $\mathrm{Cu}$ concentration and Rhizobium MPN, whereas the linear relationship to total $\mathrm{Zn}$ was statistically significant at six of the field sites (UK Water Industry Research Limited, 2002; Table 6); significant inverse relationships were also seen for total $\mathrm{Cd}$ at Gleadthorpe and Shirburn.

During 2003, cell numbers in soils receiving the $\mathrm{Cu}$ and $\mathrm{Cd}$ sludge treatments (Dose-Response Level 4) at Auchincruive and Shirburn, respectively, were significantly $(p<0.05)$ lower in comparison to the corresponding uncontaminated controls (UK Water Industry Research Limited, 2007; Table 7). During 2005, however, significant $(p<0.001)$ reductions were observed in soils receiving the $\mathrm{Zn}$ sludge treatment at seven of the LTSE field sites (Table 7), particularly at Hartwood where Rhizobium cells were not detected at Levels 2 to 4 of the $\mathrm{Zn}$ dose-response curve. Similarly at Gleadthorpe and Pwllpeiran $(p<0.01)$, as well as Hartwood $(p<0.05)$, Rhizobium MPN were significantly lower in soils receiving the Cd sludge treatment at Level 4 of the doseresponse curve. However, only at Hartwood were Rhizobium MPN in soils receiving the $\mathrm{Cu}$ sludge treatment (Level 4) significantly $(p<0.05)$ lower than in the soil receiving the uncontaminated control (Table 7). By 2005, Rhizobium MPN were now

Table 4. Properties of sludge treatments applied for 4 yr (1994-1997) at Long-Term Sludge Experiment sites.

\begin{tabular}{lccccc}
\hline Property & $\begin{array}{c}\text { Control 1 } \\
\text { (digested sludge) }\end{array}$ & $\begin{array}{c}\text { Control 2 } \\
\text { (undigested sludge) }\end{array}$ & $\begin{array}{c}\text { Zn } \\
\text { (digested sludge) }\end{array}$ & $\begin{array}{c}\text { Cu } \\
\text { (undigested sludge) }\end{array}$ & $\begin{array}{c}\text { Cd } \\
\text { (digested sludge) }\end{array}$ \\
\hline Dry matter, \% & 18.3 & 36.7 & 23.5 & 18.0 & 67.8 \\
Organic C, \% & 38.1 & 42.9 & 31.6 & 37.6 & 12.9 \\
$\mathrm{pH}$ & 7.3 & 7.3 & 7.5 & 5.2 & 6.8 \\
$\mathrm{Zn}, \mathrm{mg} \mathrm{kg}^{-1}$ & 560 & 490 & $\mathbf{6 0 0 0 +}$ & 550 & 1100 \\
$\mathrm{Cu}, \mathrm{mg} \mathrm{kg}^{-1}$ & 590 & 450 & $\mathbf{1 4 0 0}$ & $\mathbf{5 0 5 0}$ & 540 \\
$\mathrm{Cd}, \mathrm{mg} \mathrm{kg}^{-1}$ & 1.8 & 1.7 & 11.2 & 0.7 & $\mathbf{4 4}$ \\
\hline
\end{tabular}

† Values in bold are above EU Sludge Directive lower limits for the respective metal concentrations in sludge: $\mathrm{Zn}, 2500-4000 \mathrm{mg} \mathrm{kg}^{-1} ; \mathrm{Cu}, 1000-1750$ $\mathrm{mg} \mathrm{kg}^{-1} ; \mathrm{Cd}, 20-40 \mathrm{mg} \mathrm{kg}^{-1}$ (CEC, 1986).

Table 5. Total metal concentrations measured for each of the Long-Term Sludge Experiment sites in 1997 (adapted from Gibbs et al. 2006).

\begin{tabular}{|c|c|c|c|c|c|c|c|c|c|}
\hline \multirow{2}{*}{$\begin{array}{l}\text { Sludge } \\
\text { treatment }\end{array}$} & \multicolumn{9}{|c|}{ Metal concentrations measured in 1997} \\
\hline & Auchincruive & Bridgets & Gleadthorpe & Hartwood & Pwllpeiran & Rosemaund & Shirburn & Watlington & Woburn \\
\hline & & & & & $-\mathrm{mg} \mathrm{kg}^{-1}$ & & & & \\
\hline Zn 1 & $147(1.8) \dagger$ & $202(27.7)$ & $134(6.6)$ & $171(16.8)$ & $212(8.3)$ & $152(5.3)$ & $185(5.9)$ & $203(14.0)$ & $125(14.1)$ \\
\hline $\operatorname{Zn} 2$ & $236(10.2)$ & $299(17.9)$ & $232(49.0)$ & $240(11.6)$ & $274(2.4)$ & $251(4.5)$ & $298(20.4)$ & $304(35.5)$ & $211(8.1)$ \\
\hline Zn 3 & $314(8.1)$ & $414(9.3)$ & $334(44.4)$ & $406(30.9)$ & $371(17.1)$ & $444(8.0)$ & $345(5.4)$ & $459(21.6)$ & $304(24.9)$ \\
\hline Zn $4 \neq$ & $342(30.3)$ & $459(51.0)$ & $291(29.4)$ & $443(4.2)$ & $370(20.5)$ & $421(34.7)$ & $414(17.5)$ & $539(10.6)$ & $224(16.4)$ \\
\hline $\mathrm{Cu} 1$ & $66(4.2)$ & $75(2.7)$ & $69(6.8)$ & $74(8.4)$ & $81(2.9)$ & $74(5.5)$ & $76(7.2)$ & $109(0.3)$ & $56(3.3)$ \\
\hline $\mathrm{Cu} 2$ & $103(9.1)$ & $136(2.4)$ & $120(18.3)$ & $129(6.6)$ & $182(13.7)$ & $137(17.7)$ & $140(5.9)$ & $178(28.1)$ & $92(10.3)$ \\
\hline Cu 3 & $140(17.0)$ & $212(1.0)$ & $188(39.4)$ & $195(15.7)$ & $202(15.3)$ & $202(38.7)$ & $171(2.1)$ & $254(14.1)$ & $161(15.0)$ \\
\hline $\mathrm{Cu} 4 \neq$ & $206(31.6)$ & 209 (3.8) & $166(23.6)$ & $239(17.1)$ & $234(37.9)$ & $219(21.8)$ & $224(12.6)$ & $309(26.4)$ & $188(37.6)$ \\
\hline $\mathrm{Cd} 1$ & $1.0(<0.01)$ & $1.8(0.38)$ & $1.0(0.20)$ & $1.2(0.09)$ & $1.1(0.07)$ & $1.0(0.04)$ & $1.3(0.14)$ & $1.3(0.06)$ & $0.8(0.08)$ \\
\hline $\mathrm{Cd} 2$ & $2.6(0.29)$ & $2.5(0.28)$ & $1.9(0.13)$ & $2.0(0.06)$ & $2.3(0.39)$ & $1.7(0.090$ & $2.1(0.23)$ & $2.5(0.17)$ & $1.7(0.22)$ \\
\hline $\mathrm{Cd} 3$ & $3.4(0.39)$ & $3.4(0.21)$ & $2.8(0.17)$ & $3.4(0.10)$ & $3.4(0.14)$ & $2.1(0.85)$ & $3.5(0.20)$ & $4.0(0.11)$ & $2.9(0.17)$ \\
\hline $\mathrm{Cd} 4 \neq$ & $3.8(0.22)$ & $4.7(0.42)$ & $3.3(0.21)$ & $4.6(0.13)$ & $4.2(0.56)$ & $3.7(0.02)$ & $4.1(0.31)$ & $4.8(0.16)$ & $3.5(0.37)$ \\
\hline
\end{tabular}

† Values in parentheses are standard errors $(n=3)$.

‡ Values of $\mathrm{Zn}, \mathrm{Cu}$, and Cd for dose-response Level 5 at Shirburn are $579 \pm 20.3,262 \pm 12.6$, and $5.0 \pm 0.44 \mathrm{mg} \mathrm{kg}^{-1}$, respectively. 
significantly and inversely related with total $\mathrm{Zn}$ at eight of the nine LTSE field sites, with significant relationships also observed at four of the sites for both total $\mathrm{Cu}$ and total Cd (Table 6).

A common tendency of primary studies is to focus predominantly on statistical significance rather than effect size. It is often assumed that the absence of statistical significance provides evidence for the null hypothesis, hence the total number of significant results is compared with that of nonsignificant results to determine whether an effect exists or not (Hedges and Olkin,
1980). In the case of the LTSE, from a total of 459 measurements of Rhizobium MPN, during the course of $8 \mathrm{yr}$, only 23 were reported to be significantly lower in soils treated with contaminated sludge than in soils receiving the corresponding uncontaminated controls (Table 7$)$. Similarly, less than half $(n=40)$ of a possible 105 linear relationships were reported to be statistically significant (Table 6). However, nonsignificant results can simply be due to low statistical power where small sample sizes have been used in primary studies (Borenstein, 2000). In this

Table 6. A summary of statistically significant inverse relationships found between Rhizobium cell numbers (log 10 cells $\mathrm{g}^{-1}$ soil) and total metal concentration ( $\mathrm{mg} \mathrm{kg}^{-1}$ ) during the course of the Long-Term Sludge Experiment (1999-2005) (data compiled from Gibbs et al., 2006; UK Water Industry Research Limited, 2002, 2007).

\begin{tabular}{|c|c|c|c|c|c|c|c|c|c|}
\hline $\begin{array}{l}\text { Sludge } \\
\text { Treatment }\end{array}$ & Auchincruive & Bridgets & Gleadthorpe & Hartwood & Pwllpeiran & Rosemaund & Shirburn & Watlington & Woburn \\
\hline & & & & & 1999 & & & & \\
\hline $\mathrm{Zn}$ & - & - & $\begin{array}{l}p<0.001 \\
R^{2}=59 \%\end{array}$ & - & - & - & - & $\begin{array}{c}p<0.05 \\
R^{2}=34 \%\end{array}$ & - \\
\hline \multirow[t]{2}{*}{$\mathrm{Cu}$} & - & - & $\begin{array}{l}p<0.001 \\
R^{2}=62 \%\end{array}$ & $\begin{array}{c}p<0.01 \\
R^{2}=50 \%\end{array}$ & - & $\begin{array}{c}p<0.05 \\
R^{2}=35 \%\end{array}$ & - & $\begin{array}{c}p<0.01 \\
R^{2}=57 \%\end{array}$ & $\begin{array}{c}p<0.05 \\
R^{2}=34 \%\end{array}$ \\
\hline & & & & & 2001 & & & & \\
\hline $\mathrm{Zn}$ & - & $\begin{array}{c}p<0.01 \\
R^{2}=52 \%\end{array}$ & $\begin{array}{l}p<0.001 \\
R^{2}=73 \%\end{array}$ & $\begin{array}{c}p<0.01 \\
R^{2}=44 \%\end{array}$ & $\begin{array}{l}p<0.001 \\
R^{2}=73 \%\end{array}$ & $\begin{array}{l}p<0.001 \\
R^{2}=59 \%\end{array}$ & - & $\begin{array}{c}p<0.01 \\
R^{2}=47 \%\end{array}$ & - \\
\hline $\mathrm{Cu}$ & - & - & - & - & - & - & - & - & - \\
\hline \multirow[t]{2}{*}{$\mathrm{Cd}$} & - & - & $\begin{array}{c}p<0.01 \\
R^{2}=54 \%\end{array}$ & - & - & - & $\begin{array}{c}p<0.05 \\
R^{2}=35 \%\end{array}$ & - & - \\
\hline & & & & & 2003 & & & & \\
\hline $\mathrm{Zn}$ & - & $\begin{array}{c}p<0.05 \\
R^{2}=22 \%\end{array}$ & $\begin{array}{l}p<0.001 \\
R^{2}=39 \%\end{array}$ & $\begin{array}{l}p<0.001 \\
R^{2}=78 \%\end{array}$ & - & $\begin{array}{c}p<0.05 \\
R^{2}=28 \%\end{array}$ & - & $\begin{array}{c}p<0.01 \\
R^{2}=19 \%\end{array}$ & $\begin{array}{c}p<0.01 \\
R^{2}=37 \%\end{array}$ \\
\hline $\mathrm{Cu}$ & $\begin{array}{l}p<0.001 \\
R^{2}=14 \%\end{array}$ & - & - & - & - & - & - & - & - \\
\hline \multirow[t]{2}{*}{$\mathrm{Cd}$} & - & - & - & - & - & $\begin{array}{l}p<0.001 \\
R^{2}=27 \%\end{array}$ & $\begin{array}{c}p<0.01 \\
R^{2}=25 \%\end{array}$ & - & - \\
\hline & & & & & 2005 & & & & \\
\hline $\mathrm{Zn}$ & $\begin{array}{l}p<0.001 \\
R^{2}=32 \%\end{array}$ & $\begin{array}{c}p<0.01 \\
R^{2}=13 \%\end{array}$ & $\begin{array}{c}p<0.01 \\
R^{2}=33 \%\end{array}$ & $\begin{array}{c}p<0.01 \\
R^{2}=100 \%\end{array}$ & $\begin{array}{c}p<0.05 \\
R^{2}=43 \%\end{array}$ & $\begin{array}{l}p<0.001 \\
R^{2}=47 \%\end{array}$ & - & $\begin{array}{l}p<0.001 \\
R^{2}=27 \%\end{array}$ & $\begin{array}{l}p<0.001 \\
R^{2}=59 \%\end{array}$ \\
\hline $\mathrm{Cu}$ & - & $\begin{array}{l}p<0.05 \\
R^{2}=5 \%\end{array}$ & - & $\begin{array}{l}p<0.001 \\
R^{2}=26 \%\end{array}$ & $\begin{array}{c}p<0.05 \\
R^{2}=16 \%\end{array}$ & $\begin{array}{l}p<0.05 \\
R^{2}=7 \%\end{array}$ & - & - & - \\
\hline $\mathrm{Cd}$ & - & - & $\begin{array}{c}p<0.01 \\
R^{2}=21 \%\end{array}$ & $\begin{array}{c}p<0.05 \\
R^{2}=47 \%\end{array}$ & $\begin{array}{c}p<0.01 \\
R^{2}=20 \%\end{array}$ & - & - & - & $\begin{aligned} p & <0.05 \\
R^{2} & =18 \%\end{aligned}$ \\
\hline
\end{tabular}

Table 7. A summary of instances where Rhizobium cell numbers (log10 cells $\mathrm{g}^{-1}$ soil) were significantly lower in soils treated with contaminated sludge than in soils receiving corresponding "uncontaminated" sludge treatments during the course of the Long-Term Sludge Experiment (19992005) (data compiled from UK Water Industry Research Limited, 2002, 2007).

\begin{tabular}{|c|c|c|c|c|c|c|c|c|c|}
\hline $\begin{array}{l}\text { Dose- } \\
\text { response level }\end{array}$ & Auchincruive & Bridgets & Gleadthorpe & Hartwood & Pwllpeiran & Rosemaund & Shirburn & Watlington & Woburn \\
\hline & \multicolumn{9}{|c|}{2003} \\
\hline $\mathrm{Cu}(4)$ & $\begin{array}{c}p<0.05 \\
(32) \dagger\end{array}$ & - & - & - & - & - & - & - & - \\
\hline \multirow[t]{2}{*}{$\mathrm{Cd}(4)$} & - & - & - & - & - & - & $\begin{array}{c}p<0.05 \\
(30)\end{array}$ & - & - \\
\hline & \multicolumn{9}{|c|}{2005} \\
\hline $\mathrm{Zn}(1)$ & - & - & - & $\begin{array}{c}p<0.001 \\
(71)\end{array}$ & - & - & - & - & - \\
\hline $\mathrm{Zn}(2)$ & - & $\begin{array}{c}p<0.001 \\
(22)\end{array}$ & $\begin{array}{c}p<0.001 \\
\quad(44)\end{array}$ & $\begin{array}{c}p<0.001 \\
(100)\end{array}$ & - & - & - & - & $\begin{array}{c}p<0.001 \\
(52)\end{array}$ \\
\hline $\mathrm{Zn}(3)$ & - & $\begin{array}{c}p<0.001 \\
(21)\end{array}$ & $\begin{array}{c}p<0.001 \\
(36)\end{array}$ & $\begin{array}{c}p<0.001 \\
(100)\end{array}$ & - & $\begin{array}{c}p<0.001 \\
\quad(42)\end{array}$ & - & $\begin{array}{c}p<0.001 \\
\quad(27)\end{array}$ & $\begin{array}{c}p<0.001 \\
(45)\end{array}$ \\
\hline $\mathrm{Zn}(4)$ & - & - & $\begin{array}{c}p<0.001 \\
(61)\end{array}$ & $\begin{array}{c}p<0.001 \\
(100)\end{array}$ & $\begin{array}{c}p<0.001 \\
(46)\end{array}$ & $\begin{array}{c}p<0.001 \\
\quad(52)\end{array}$ & - & $\begin{array}{c}p<0.001 \\
(33)\end{array}$ & $\begin{array}{c}p<0.001 \\
(85)\end{array}$ \\
\hline $\mathrm{Cu}(4)$ & - & - & - & $\begin{array}{c}p<0.05 \\
(37)\end{array}$ & - & - & - & - & - \\
\hline $\mathrm{Cd}(4)$ & - & - & $\begin{array}{c}p<0.05 \\
(30)\end{array}$ & $\begin{array}{c}p<0.05 \\
(74)\end{array}$ & $\begin{array}{c}p<0.05 \\
(33)\end{array}$ & - & - & - & - \\
\hline
\end{tabular}

† Observed decreases (\%) in soils receiving $\mathrm{Zn}, \mathrm{Cu}$, or $\mathrm{Cd}$ sludge in comparison to uncontaminated controls are shown in parentheses. 
case, the contaminated and uncontaminated sludge treatments were applied in triplicate, which may not be sufficient to overcome the natural variation in Rhizobium cell numbers observed within the soil environment. Therefore it could be that the effect of applying contaminated sewage sludge was consistently negative across all field sites (i.e., Rhizobium MPN were lower in contaminated soils) but produced nonsignificant results due to a low sample size, hence the overall effect may have been overlooked.

Meta-analysis approaches this ambiguity by focusing on the magnitude and direction of an effect, i.e., the practical significance, rather than its statistical significance (Borenstein, 2000; Borenstein et al., 2009). The goal of meta-analysis is also to test the null hypothesis of no effect; however, this is achieved by establishing a common framework in which direct comparisons can be made between independent primary studies (i). The observed effects $\left(R_{i}\right)$ are then combined to give an overall summary effect $(M)$ across a number of primary studies $(k)$, thus giving a more precise estimation of effect size. Combining studies in this way markedly increases statistical power by increasing the overall sample size and can help reduce the "noise" created by sampling error within each study (Hedges and Pigott, 2001). Meta-analysis is becoming increasingly applied within the environmental sciences to help understand a wide range of research questions. It was the aim of this study to provide an additional review of the LTSE, using the statistical methods of metaanalysis, to give a clear overview of the experimental data. This allows an evaluation of previous conclusions and an assessment of the statutory limits set by the UK Sludge (Use In Agriculture) Regulations by assessing the long-term impact of heavy metals on Rhizobium populations in contaminated soils.

\section{Methods}

\section{Data Sources and Treatment}

Data were used from previously published results. For each of the LTSE field sites, Rhizobium MPN across all doseresponse levels were reported for 1999 (with the exception of Auchincruive), 2001, 2003, and 2005 by UK Water Industry Research Limited (2002, 2007). Gibbs et al. (2006) reported Rhizobium MPN for each of the LTSE field sites measured during 1997 at Dose-Response Level 3; however, no standard errors (or standard deviations) were reported for the data and hence effect sizes could not be calculated. Where standard errors have been reported as 0.00 , these values were set equal to 0.001 . In addition, values reported as $<x$ (i.e., lower than the limit of detection) have been set equal to $x$; this was necessary for some of the data from Hartwood. In all cases, Rhizobium MPN were determined using the methods described by Vincent (1970) and Woomer et al. (1990) and reported as the arithmetic mean $(\bar{x})$ of three replicates $(n=3)$ with standard error $(\mathrm{SE})$; all standard errors were converted to standard deviations $(S D=S E \times \sqrt{ } n)$. Total concentrations $\left(\mathrm{mg} \mathrm{kg}^{-1}\right)$ of $\mathrm{Zn}, \mathrm{Cu}$, and $\mathrm{Cd}$, were also recorded as covariables. All data included in the meta-analysis are presented in the supplemental material (Supplemental Table S1). Analysis of Rhizobium MPN was performed by three laboratories at separate institutions: Rothamsted Research (for all sites in England and Wales), the Macaulay Institute (for Hartwood), and SAC (for Auchincruive). Therefore a quality assurance program was implemented to determine inter-laboratory precision and variability. No significant differences in Rhizobium MPN data were observed among the three laboratories, none of which could detect Rhizobium cells in the Hartwood soil sampled from plots receiving the $\mathrm{Zn}$ sludge treatment at Dose-Response Level 4 (UK Water Industry Research Limited, 2007). Hence the LTSE data set, as a whole, allows comparisons to be made among sites with a considerable degree of confidence, which would not necessarily be the case if a data set for meta-analysis was compiled from a number of independent, and international, long-term sludge experiments with various experimental designs.

For the purposes of meta-analysis, an experimental treatment (E) must be compared with a suitable control (C). Hence the Rhizobium cell numbers in soils receiving the $\mathrm{Zn}$ and $\mathrm{Cd}$ sludge treatments were compared with those in soils receiving the uncontaminated digested sludge (Control 1; Table 4), whereas Rhizobium cell numbers in soils receiving the $\mathrm{Cu}$ sludge treatment were compared with that in soils receiving the uncontaminated undigested sludge (Control 2; Table 4). Each dose-response level (Levels 1-4, plus Level 5 only at Shirburn) at each of the nine LTSE field sites was considered as an independent primary "study," giving a total of $k=37$ studies for the three contaminated sludge treatments following each of the sampling events (except for 1999, when $k=33$ ). Individual meta-analyses were performed for each sludge treatment, grouping the data according to soil texture and total metal concentration. Finally, the data for each sludge treatment were grouped according to the date of each sampling event $(1999,2001,2003$, and 2005) to investigate the changes in effect with time; a cumulative effect was also calculated by combining data for successive sampling events.

Due to variations in soil type and climate, and discrepancies between the target metal concentrations and those actually achieved (UK Water Industry Research Limited, 2002, 2007; Department for Environment, Food and Rural Affairs, 2008), it could not be assumed that the overall effect on Rhizobium cell numbers would be the same for each of the nine field sites, although the experimental design and applied sludge treatments were identical. Therefore a random effect model was chosen when calculating summary effects for the meta-analysis overall (Borenstein et al., 2009; Hedges and Vevea, 1998), with the data from each site considered to be an individual sample from a population of possible effects. This model assumes that the true effect sizes for each individual study are normally distributed about a mean value and takes into account both sampling error within each study and the true variation in effects observed among sites.

\section{Meta-Analysis}

All calculations were performed according to Borenstein et al. (2009). Effects were calculated for each independent study as the log response ratio (Hedges et al., 1999):

$R_{i}=\frac{\bar{x}_{\mathrm{E}}}{\bar{x}_{\mathrm{C}}}$

$\ln \left(R_{i}\right)=\ln \left(\frac{\bar{x}_{\mathrm{E}}}{\bar{x}_{\mathrm{C}}}\right)=\ln \bar{x}_{\mathrm{E}}-\ln \bar{x}_{\mathrm{C}}$

where $\bar{x}_{\mathrm{E}}$ and $\bar{x}_{\mathrm{C}}$ are the respective means of the experimental and control groups. The within-study variance $(V)$ and standard error $\left(\mathrm{SE}_{i}\right)$ of each effect were then calculated as 
$V_{i}=\left(\frac{\mathrm{SD}_{\mathrm{E}}^{2}}{n_{\mathrm{E}} \bar{x}_{\mathrm{E}}^{2}}\right)+\left(\frac{\mathrm{SD}_{\mathrm{C}}^{2}}{n_{\mathrm{C}} \bar{x}_{C}^{2}}\right)$

$\mathrm{SE}_{i}=\sqrt{V_{i}}$

where $\mathrm{SD}_{\mathrm{E}}$ and $n_{\mathrm{E}}$ and $\mathrm{SD}_{\mathrm{C}}$ and $n_{\mathrm{C}}$ are the standard deviation and sample size of the experimental and control groups, respectively. Except when the data were grouped by year, the effect sizes calculated for each sampling event $(j)$ were combined to give an average effect for each independent study during the experiment:

$\bar{R}_{i j}=\frac{1}{m}\left(\sum_{j}^{m} R_{i j}\right)$

where $m$ is the total number of sampling events $(m=4[1999$, 2001, 2003, and 2005]; for Auchincruive, $m=3$ [2001, 2003, and 2005]); mean within-study variances $\left(\bar{V}_{i j}\right)$ and standard errors $\left(\overline{\mathrm{SE}}_{i j}\right)$ were also calculated in the same way. Effects were then weighted $\left(W_{i j}\right)$, using the reciprocal of Eq. [3] and substituting the mean variance for each independent study $\left(1 / \bar{V}_{i j}\right)$. Lower (LL) and upper (UL) confidence limits were determined as

$$
\begin{aligned}
\mathrm{LL}_{i} & =\bar{R}_{i j}-1.96 \times \overline{\mathrm{SE}}_{i j} \\
\mathrm{UL}_{i} & =\bar{R}_{i j}+1.96 \times \overline{\mathrm{SE}}_{i j}
\end{aligned}
$$

where 1.96 is the $Z$ value corresponding to a confidence limit of $95 \%$. A two-tailed test of the null hypothesis $(\alpha=0.05)$ was then performed for each individual study:

$\mathrm{Z}_{i}=\frac{\bar{R}_{i j}}{\overline{\mathrm{SE}}_{i j}}$

As mentioned above, the overall variance for each individual study in the random effects model $\left(\bar{V}_{i j}^{*}\right)$ is the sum of the withinstudy variance plus the between-study variance $\left(T^{2}\right)$ :

$\bar{V}_{i j}^{*}=\bar{V}_{i j}+T^{2}$

An estimate of the between-study variance was therefore determined by calculating the $Q$ statistic: the weighted sum of squares across all studies in the meta-analysis, representing the total observed variation (Borenstein et al., 2009):

$$
Q=\sum_{i=1}^{k} W_{i j} \bar{R}_{i j}^{2}-\frac{\left(\sum_{i=1}^{k} W_{i j} \bar{R}_{i j}\right)^{2}}{\sum_{i=1}^{k} W_{i j}}
$$

The difference between $Q$ and the degrees of freedom $(\mathrm{df}=k-1)$, assuming a fixed effect size for all studies (i.e., $T^{2}=0$ ), then represents the true variation between effect sizes:

$T^{2}=\frac{(Q-\mathrm{df})}{C}$

where $C$ is a quantity used to give units of the original metric:

$C=\sum_{i=1}^{k} W_{i j}-\frac{\sum_{i=1}^{k} W_{i j}^{2}}{\sum_{i=1}^{k} W_{i j}}$
Because it was not assumed that the between-study variance would be the same for each subgroup, separate values of $T^{2}$ were calculated in each case. Finally, summary effect sizes were calculated as the weighted mean across all studies within each group:

$$
M=\frac{\sum_{i=1}^{k} \bar{W}_{i j}^{*} \bar{R}_{i j}}{\sum_{i=1}^{k} \bar{W}_{i j}^{*}}
$$

where $\bar{W}_{i j}{ }^{*}$ is the weight assigned to each individual study based on the overall mean variance (Eq. [9]) for each study. The variance $\left(V_{M}\right)$ of the summary effect was then calculated as the reciprocal of $\bar{W}_{i j}{ }^{*}$, using the sum of weights:

$V_{M}=\frac{1}{\sum_{i=1}^{k} \bar{W}_{i j}^{*}}$

The standard error $\left(\mathrm{SE}_{M}\right)$ was calculated as above (Eq. [3]) using the summary variance, following which $95 \%$ confidence limits and statistical significance were determined by substituting $M$ and $\mathrm{SE}_{M}$ into Eq. [6], [7], and [8], respectively. The summary effect and $95 \%$ confidence limits $\left(\mathrm{LL}_{M}\right.$ and $\left.\mathrm{UL}_{M}\right)$ were then converted back into the original metric (i.e., $\log _{10}$ cells $\mathrm{g}^{-1}$ soil) and expressed as a percentage of the overall increase or decrease:

$M(\%)=100-[\exp (M) \times 100]=100-\left(\frac{M_{\mathrm{E}}}{M_{\mathrm{C}}} 100\right)$

Calculated effect sizes represent the percentage difference in the $\log _{10}$ of Rhizobium cell numbers in soils receiving contaminated sludge treatments compared with soils receiving uncontaminated sludge treatments. Therefore the actual percentage difference in Rhizobium cell numbers will be much greater, particularly if Rhizobium MPN is a low value. The results for each meta-analysis are presented as "forest plots," where each point represents the overall effect size for an individual subgroup. For clarity, only summary effect sizes are shown; effects calculated for individual studies are given in the supplemental material (Supplemental Table S1). The 95\% confidence limits for each effect size are represented as horizontal lines; the observed effect is not statistically significant if the $95 \%$ confidence limit spans the center line, at which point the effect size is equal to $0\left(\bar{x}_{\mathrm{E}}=\bar{x}_{\mathrm{C}}\right)$.

\section{Results}

\section{Soil Texture}

Zinc

Figure 2a shows the summary effect sizes calculated for the $\mathrm{Zn}$ sludge treatment grouped according to soil texture. In each case, the observed effects were negative and statistically significant $(p<$ 0.001 ). The $\mathrm{Zn}$ sludge treatment appeared to have the least effect on Rhizobium MPN in the calcareous clay loam soil at Shirburn $\left(-12.1 \%\right.$; confidence limit $\mathrm{CL}_{95 \%}=-17.0$ to $\left.-6.0 \%\right)$. For the silty clay loam, clay loam, and sandy loam soils, the $\mathrm{Zn}$ sludge treatment appeared to have a similar effect on Rhizobium MPN, with overall effects ranging from -24.0 to $-21.8 \%$, while the greatest effect $\left(-48.0 \% \mathrm{CL}_{95 \%}=-64.4\right.$ to $\left.-23.8 \%\right)$ observed was in the sandy clay loam soils of the Scottish field sites (Auchincruive and Hartwood). This was largely due to the Rhizobium MPN being below the detection limit at Dose-Response Levels 3 and 

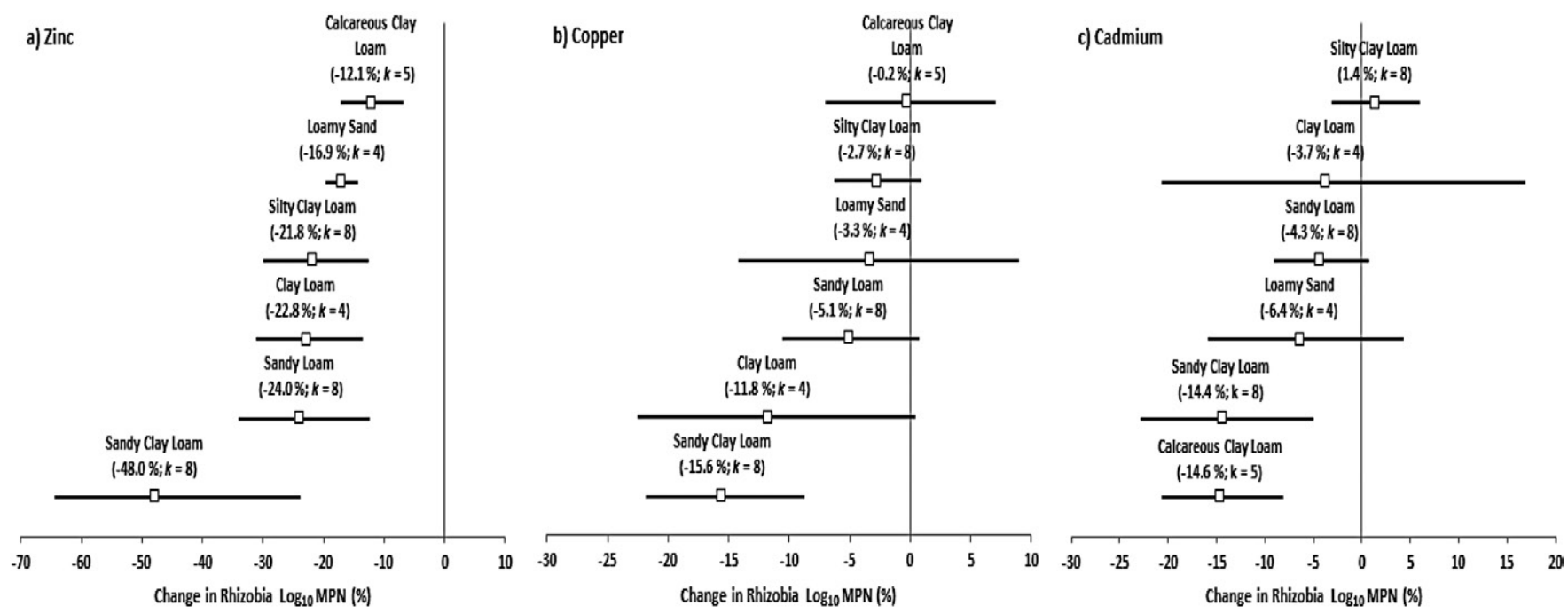

Fig. 2. Forest plots showing effects of (a) $\mathrm{Zn}$, (b) Cu, and (c) Cd sludge treatments on Rhizobium most probable number of cells (MPN) grouped according to soil texture. Each point (口) represents the summary effect size for each soil type included in the Long-Term Sludge Experiment. The number of primary studies $(k)$ used to calculate each effect size is indicated. Horizontal lines represent $95 \%$ confidence limits. Effects are not statistically significant if $95 \%$ confidence limit crosses the zero line.

4 during 2003 and 2005. Calculating separate effects (across Levels 1-4) for the two Scottish field sites clearly demonstrated this, as the overall effect observed at Hartwood $\left(-63.8 \% ; \mathrm{CL}_{95 \%}\right.$ $=-70.3$ to $-55.9 \% ; p<0.001)$ was more than five times greater than the effect seen at Auchincruive $\left(-12.0 \% ; \mathrm{CL}_{95 \%}=-28.8\right.$ to $8.7 \% ; p=0.236$ ); the overall effect at Auchincruive alone was not statistically significant (data not shown). The most likely reason for the dramatic effect observed at Hartwood is the low soil $\mathrm{pH}$ (5.8), which would increase the solubility, and hence bioavailability, of heavy metal contamination. In comparison with the other field sites, concentrations of $\mathrm{Zn}$ extractable by $\mathrm{NH}_{4} \mathrm{NO}_{3}$ were consistently greater at Hartwood during the course of the LTSE (UK Water Industry Research Limited, 2002, 2007; Gibbs et al., 2006). In 1997, Gibbs et al. (2006) found the concentrations of $\mathrm{Zn}$ extractable by $\mathrm{NH}_{4} \mathrm{NO}_{3}$ to be inversely proportional $\left(R^{2}=92 \% ; p<0.001\right)$ to the soil $\mathrm{pH}$, which would also explain why the effect of the $\mathrm{Zn}$ sludge treatment was lowest at Shirburn. Copper

The effect of the $\mathrm{Cu}$ sludge treatment in the different soil types was lower than that of $\mathrm{Zn}$. In each case, the observed effects were negative; however, only in the sandy clay loam soils was the observed effect statistically significant (Fig. 2b). As observed for the $\mathrm{Zn}$ sludge treatment, $\mathrm{Cu}$ also had the greatest impact in the Scottish sandy clay loam soils $\left(-15.6 \%\right.$; $\mathrm{CL}_{95 \%}=-21.8$ to $-8.8 ; p<0.001)$. However, in this case, the individual effects of $\mathrm{Cu}$ on Rhizobium MPN seen at Auchincruive $(-14.9 \%$; $\mathrm{CL}_{95 \%}=-29.3$ to $\left.2.4 \% ; p=0.088\right)$ and Hartwood $(-15.7 \%$; $\mathrm{CL}_{95 \%}=-22.5$ to $\left.-8.2 ; p<0.001\right)$ were approximately equal, although again the effect at Auchincruive was not statistically significant (data not shown). It is unclear why $\mathrm{Cu}$ would have such a significant effect at the Hartwood site because $\mathrm{Cu}$ is readily immobilized by soil organic matter, which was greatest at the Hartwood site (Table 2). Gibbs et al. (2006) observed no significant relationship between soil $\mathrm{pH}$ and the $\mathrm{NH}_{4} \mathrm{NO}_{3}$-extractable $\mathrm{Cu}$ in 1997 but did find extractable $\mathrm{Cu}$ to be inversely proportional $(p<0.001)$ to soil Fe content, accounting for $64 \%$ of the observed variation, although the lowest Fe content was observed at the Gleadthorpe site (Table 2). In contrast, a slight positive relationship ( $p<0.001$ ) was observed between extractable $\mathrm{Cu}$ and soil Mn content, which accounted for an additional $14 \%$ of the observed variation when included in the original regression model. In this case, the greatest Mn content was seen at Hartwood (Table 2).

\section{Cadmium}

Only in the calcareous clay loam and sandy clay loam soils were the overall effects of the Cd sludge treatment statistically significant. In general, the effect of the Cd sludge treatment appeared to be similar in magnitude to that of $\mathrm{Cu}$; however, in contrast to both the $\mathrm{Zn}$ and $\mathrm{Cu}$ sludge treatments, the greatest impact on Rhizobium MPN was seen in the calcareous clay loam $\left(-14.6 \% ; \mathrm{CL}_{95 \%}=-20.7\right.$ to $\left.-8.1 \% ; p=<0.001\right)$ soil at Shirburn (Fig. 2c), although, in agreement with the results for the previous two sludge treatments, an effect similar in magnitude $(-14.4 \%$; $\mathrm{CL}_{95 \%}=-22.9$ to $\left.-5.0 \% ; p<0.01\right)$ was also seen at the Scottish field sites. In this case, the overall effect at Hartwood $(-22.0 \%$; $\mathrm{CL}_{95 \%}=-36.7$ to $\left.-3.9 \% ; p<0.05\right)$ was twice that observed at Auchincruive $\left(-11.7 \% ; \mathrm{CL}_{95 \%}=-21.7\right.$ to $\left.-0.4 \% ; p<0.05\right)$, with significant effects seen at both sites (data not shown). Gibbs et al. (2006) also reported an inverse linear relationship $\left(R^{2}=72 \% ; p<0.001\right)$ between $\mathrm{NH}_{4} \mathrm{NO}_{3}$-extractable $\mathrm{Cd}$ and soil $\mathrm{pH}$, hence this is also likely to be due to low soil $\mathrm{pH}(6$ and 5.8 for Auchincruive and Hartwood, respectively). However, the overall effect observed at Shirburn is anomalous to this trend. During the course of the LTSE, the mean total concentration of $\mathrm{Zn}$ in soils receiving the $\mathrm{Cd}$ sludge treatment at Shirburn ranged from 98.3 to $202.7 \mathrm{mg} \mathrm{kg}^{-1}$; hence this effect is likely to have been due to confounding metal contamination (see below).

\section{Total Metal Concentration}

Zinc

A clear decline in Rhizobium MPN can be seen with increasing total $\mathrm{Zn}$ concentration, reaching an overall effect of $-40.3 \%$ $\left(\mathrm{CL}_{95 \%}=-54.9\right.$ to $\left.-21.1 \% ; p<0.001\right)$, where the mean total $\mathrm{Zn}$ during the course of the LTSE exceeded $350 \mathrm{mg} \mathrm{kg}^{-1}$ (Fig. 3a); 
this was predominantly in soils receiving the $\mathrm{Zn}$ sludge treatment at Dose-Response Level $4\left(450 \mathrm{mg} \mathrm{Zn} \mathrm{kg}{ }^{-1}\right)$. However, more concerning is the negative effects observed in soils where the total concentration of $\mathrm{Zn}$ was below the UK statutory and advisory limit for $\mathrm{Zn}$ in sludge-amended soils. Rhizobium MPN were reduced by approximately $20 \%\left(\mathrm{CL}_{95 \%}=-27.2\right.$ to $-11.4 \%$; $p<0.001)$ in soils where total $\mathrm{Zn}$ ranged from 200 to $<300$ $\mathrm{mg} \mathrm{kg}{ }^{-1}$, with a decrease of $-13.9 \%\left(\mathrm{CL}_{95 \%}=-23.0\right.$ to $-3.7 \%$; $p<0.01$ ) also observed in soils where total $\mathrm{Zn}$ ranged from 100 to $<200 \mathrm{mg} \mathrm{kg}^{-1}$. This would suggest that even the proposed advisory limit of $200 \mathrm{mg} \mathrm{kg}^{-1}$ (for soils with $\mathrm{pH}$ 5-7) may not be sufficient to protect Rhizobium populations.

\section{Copper}

Below $100 \mathrm{mg} \mathrm{kg}^{-1}$, predominantly at Dose-Response Level 1 ( $50 \mathrm{mg} \mathrm{Cd} \mathrm{kg}^{-1}$ ), the Cu sludge treatment had no overall effect $\left(-0.2 \% ; \mathrm{CL}_{95 \%}=-4.2\right.$ to $\left.3.9 \% ; p=0.910\right)$ on Rhizobium MPN (Fig. 3b). However, as the total concentration of $\mathrm{Cu}$ increased, significant reductions in Rhizobium cell numbers were observed. For soils where the mean total $\mathrm{Cu}$ ranged from 170 to $<200 \mathrm{mg} \mathrm{kg}^{-1}$ or was $>200 \mathrm{mg} \mathrm{kg}^{-1}$, the overall effect of the $\mathrm{Cu}$ sludge treatment was approximately $-10 \%$.

\section{Cadmium}

No significant effects were observed in soils where total $\mathrm{Cd}$ ranged from 0.5 to $<1 \mathrm{mg} \mathrm{kg}^{-1}\left(-0.9 \% ; \mathrm{CL}_{95 \%}=-6.5\right.$ to $5.1 \%$; $p=0.772$ ); with the exception of the Bridgets and Woburn sites, this was also predominantly in soils receiving the $\mathrm{Cd}$ sludge treatment at Dose-Response Level 1. In soils where the mean total $\mathrm{Cd}$ ranged from 1.5 to $<2 \mathrm{mg} \mathrm{kg}^{-1}\left(-6.2 \% ; \mathrm{CL}_{95 \%}=-13.8\right.$ to $2.2 \% ; p=0.142)$ and 2 to $<3 \mathrm{mg} \mathrm{kg}^{-1}\left(-4.6 \% ; \mathrm{CL}_{95 \%}=-8.9\right.$ to $-0.2 \% ; p<0.05)$, below the UK statutory limit, the overall effect size was approximately $-5 \%$, although only between 2 to $<3 \mathrm{mg} \mathrm{kg}^{-1}$ was the effect on Rhizobium MPN statistically significant (Fig. 3c). Above the UK limit of $3 \mathrm{mg} \mathrm{kg}^{-1}$, the effect of the Cd sludge treatment caused a significant decrease in Rhizobium MPN of approximately $-10 \%\left(-9.6 \% ; \mathrm{CL}_{95 \%}=-15.3\right.$ to $-3.6 \%$; $p<0.01)$.
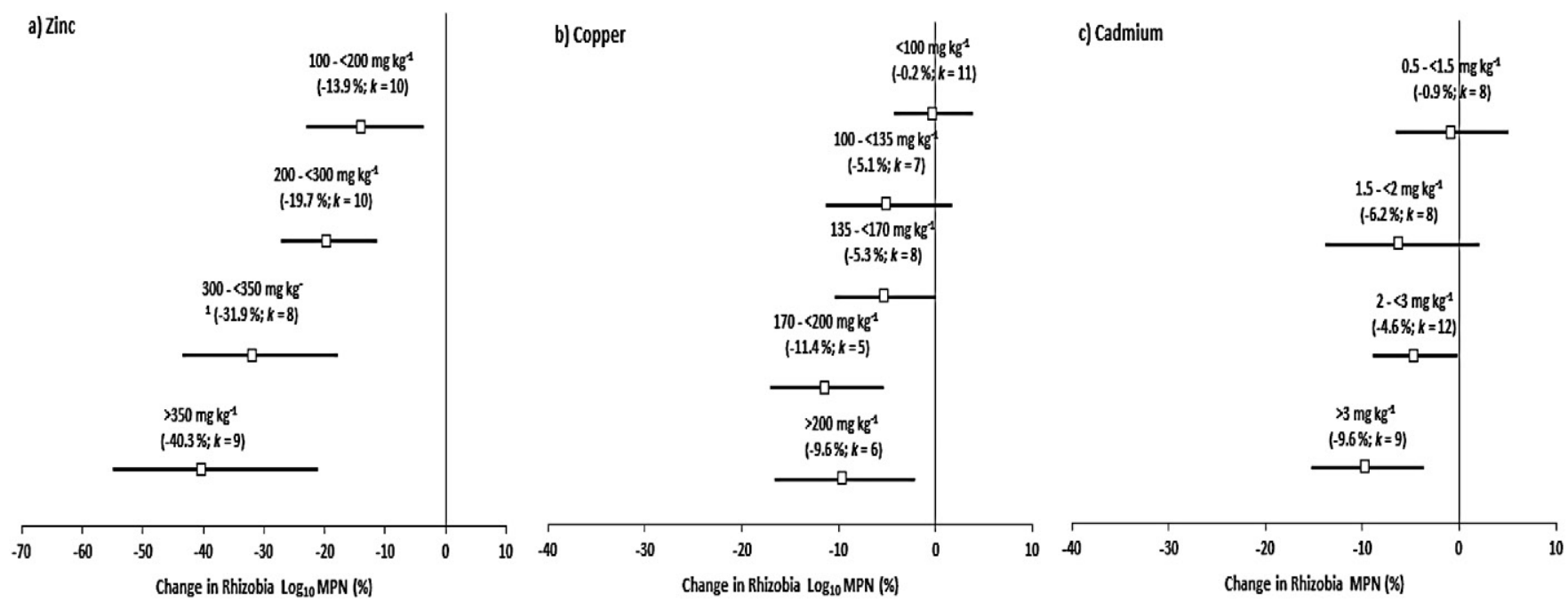

Fig. 3. Forest plots showing the effect of increasing total metal concentration on Rhizobium most probable number of cells (MPN) in soils receiving (a) $\mathrm{Zn}$, (b) $\mathrm{Cu}$, and (c) Cd sludge treatments. Each point ( $\square$ ) represents the summary effect size for data within specified concentration ranges. The number of primary studies $(k)$ used to calculate each effect size is indicated. Horizontal lines represent $95 \%$ confidence limits. Effects are not statistically significant if $95 \%$ confidence limit crosses the zero line.

\section{Change in Effect with Time}

\section{Zinc}

A clear decrease in Rhizobium MPN can be seen in soils receiving the $\mathrm{Zn}$ sludge treatment during the course of the LTSE, with the overall effect following each sampling event decreasing from $-19.0 \%\left(\mathrm{CL}_{95 \%}=-21.8\right.$ to $\left.-16.0 \% ; p<0.001\right)$ in 1999 to $-35.7 \%\left(\mathrm{CL}_{95 \%}=-46.2\right.$ to $\left.-23.2 \% ; p<0.001\right)$ in 2005 (Fig. 4a). A steady decline was also seen in the cumulative effect with time, which decreased from that observed in $1999(-19.0 \%)$ to an overall mean effect of $-26.6 \%$ (Fig. $4 \mathrm{~b}$ ). In this case, the $95 \%$ confidence limits for the 1999 sampling event overlap with those for $2005\left(\mathrm{CL}_{95 \%}=-32.7\right.$ to $-19.9 \%$; $\left.p<0.001\right)$; hence it cannot be said for certain whether the change in effect size corresponds to a significant change in Rhizobium MPN with time. Excluding data from the meta-analysis where the total concentration of $\mathrm{Zn}$ exceeded the UK statutory limits still gave a negative, and significant, cumulative effect of greater than $-20 \%(-21.1 \%$; $\mathrm{CL}_{95 \%}=-32.7$ to $-19.9 \% ; p<0.001$ ), indicating an adverse effect on Rhizobium MPN at concentrations of $\mathrm{Zn}$ below the current UK limits (data not shown). In general, this decrease was seen for each level of the dose-response curve. For soils where the total $\mathrm{Zn}$ was below the UK advisory limit (100 to $<200 \mathrm{mg}$ $\left.\mathrm{kg}^{-1}\right)$, the overall effect decreased from $-13.2 \%\left(\mathrm{CL}_{95 \%}=-24.7\right.$ to $0.1 \% ; p=0.052)$ in 1999 to $-17.5 \%\left(\mathrm{CL}_{95 \%}=-28.2\right.$ to $-5.3 \%$; $p<0.01$ ) in 2005, with significant decreases in Rhizobium MPN observed for the 2001, 2003, and 2005 sampling events (Fig. 4c). Similarly, below the UK statutory limit for soils with $\mathrm{pH} 6$ to $7\left(200\right.$ to $<300 \mathrm{mg} \mathrm{kg}^{-1}$ ), the observed effects were statistically significant for each of the sampling events (Fig. 4c). The lowest effect size observed was $-14.5 \%\left(\mathrm{CL}_{95 \%}=-21.0\right.$ to $-7.4 \%$; $p<0.001)$, seen in 2001, after which the effect size increased steadily to $-34.7 \%\left(\mathrm{CL}_{95 \%}=-50.4\right.$ to $\left.-14.1 \% ; p<0.01\right)$, although for both concentration ranges there is considerable overlap between the $95 \%$ confidence limits for each of the sampling events. Above $300 \mathrm{mg} \mathrm{kg}^{-1}$, all of the effects observed for each sampling event were statistically significant, with a general increase in effect size observed for consecutive sampling events (Fig. 4c). A dramatic decrease in Rhizobium MPN (-60.5\%;

Journal of Environmental Quality 


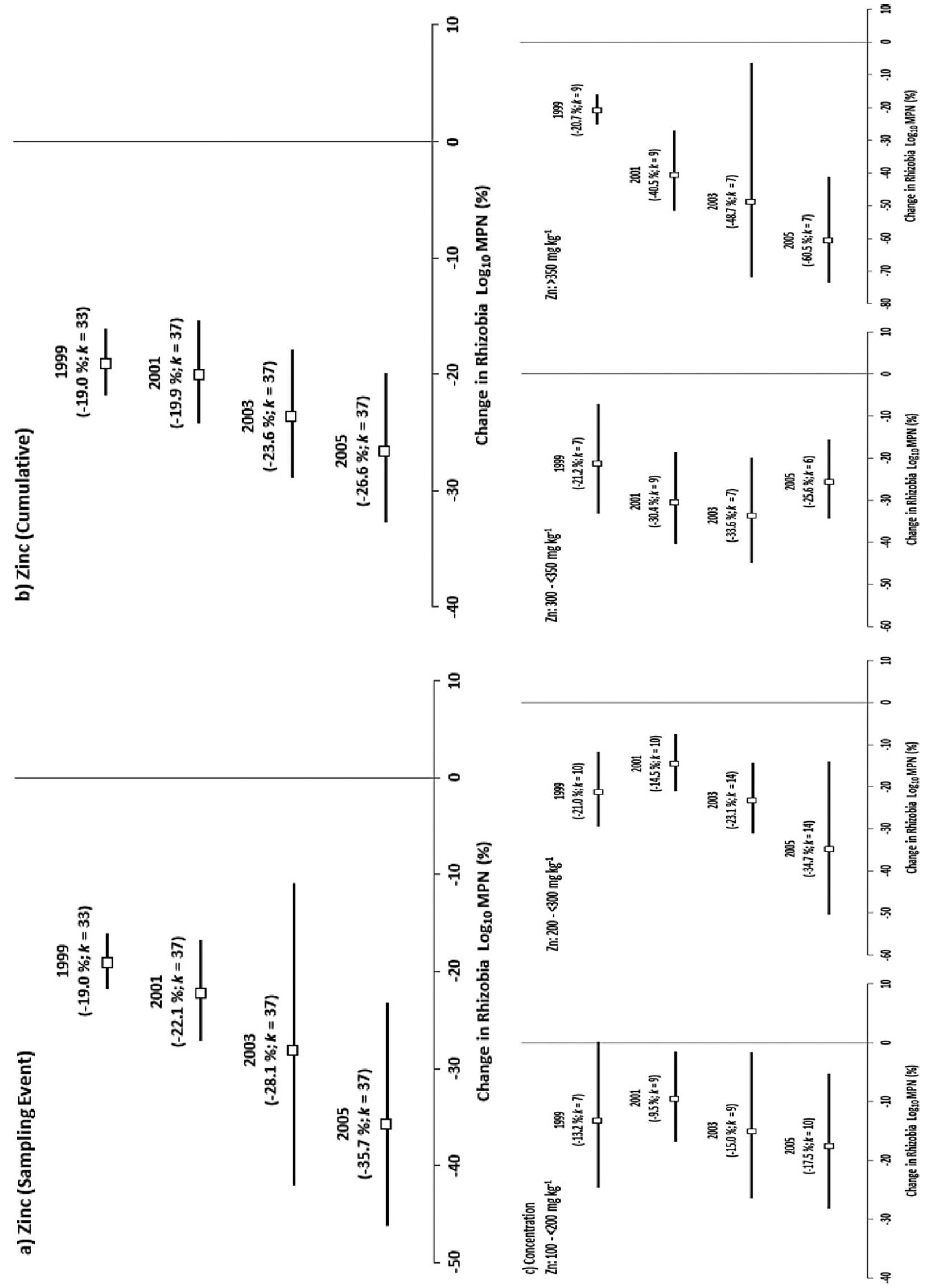

Fig. 4. Forest plots showing the change in effect of the Zn sludge treatment on Rhizobium most probable number of cells (MPN) with time: (a) after each sampling event, (b) cumulative effect with time, and (c) the change in effect with time and increasing concentrations of total $\mathrm{Zn}$. Each point (口) represents the summary effect size for specified sampling events, with the exception of the cumulative effect, which represents the mean effect over consecutive years. The number of primary studies $(k)$ used to calculate each effect size is indicated. Horizontal lines represent $95 \%$ confidence limits. Effects are not statistically significant if $95 \%$ confidence limit crosses the zero line. 
$\mathrm{CL}_{95 \%}=-73.5$ to $\left.-41.3 \% ; p<0.001\right)$ was observed for the 2005 sampling event in soils where total $\mathrm{Zn}$ remained $>350 \mathrm{mg} \mathrm{kg}^{-1}$. In this case, the effect observed after 8 yr was significantly different from that seen in $1999\left(-20.7 \% ; \mathrm{CL}_{95 \%}=-25.2\right.$ to $-16.0 \%$; $p<0.001)$. Clearly, at this level, the Zn sludge treatment has had a marked and lasting effect on Rhizobium populations in the receiving soils.

Copper

For the $\mathrm{Cu}$ sludge treatment, with the exception of 2001, a significant overall effect was seen for each of the sampling events (Fig. 5a). For the 1999 sampling event, an effect of $-7.8 \%$ $\left(\mathrm{CL}_{95 \%}=-13.3\right.$ to $\left.-1.4 \% ; p<0.05\right)$ was observed, following which the effects were $-5 \%$ or less (Fig. 5a). No significant differences were observed among the effects for each sampling event. Additionally, no significant change in the cumulative effect was observed after 2001, which remained at $-4.7 \%$ for 2003 and 2005 (Fig. 5b). Removing data where Cu exceeded the UK limit decreased the cumulative effect to $-0.8 \%\left(\mathrm{CL}_{95 \%}=-3.5\right.$ to $-2.0 \% ; p=0.570$ ), indicating that the $\mathrm{Cu}$ sludge treatment has had no overall effect on Rhizobium MPN at concentrations below the UK limit (data not shown). No statistically significant effects were observed for any of the individual sampling events below the UK limit (for soils with $\mathrm{pH}$ 6-7) of $135 \mathrm{mg} \mathrm{kg}^{-1}$, nor were any significant changes observed with time (Fig. 5c). A marked decrease in Rhizobium MPN was seen in $1999(-17.0 \%$; $\mathrm{CL}_{95 \%}=-22.8$ to $\left.-10.7 \% ; p<0.001\right)$, when total $\mathrm{Cu}$ ranged between 170 and $<200 \mathrm{mg} \mathrm{kg}^{-1}$. However, in this instance the subgroup was comprised of only $k=2$ studies and consisted of data for sandy clay loam (Hartwood) and clay loam (Pwllpeiran) soils, for which the effect of the $\mathrm{Cu}$ sludge treatment was greatest (Fig. $2 \mathrm{~b}$ and 5c). Similarly, above $200 \mathrm{mg} \mathrm{kg}^{-1}$, a decrease of $-24.3 \%\left(\mathrm{CL}_{95 \%}=-33.5\right.$ to $-13.9 \%$; $\left.p<0.001\right)$ was observed for the 2003 sampling event; again, the subgroup was predominantly comprised of data from sandy clay loam and clay loam soils. Even so, although the effect of the $\mathrm{Cu}$ sludge treatment was much lower than that of the $\mathrm{Zn}$ sludge treatment, the effects for soils where total $\mathrm{Cu}$ ranged from 135 to $<170 \mathrm{mg} \mathrm{kg}^{-1}(-10.5 \%$; $\mathrm{CL}_{95 \%}=-14.6$ to $\left.-6.2 \% ; p<0.001\right)$ and 170 to $<200 \mathrm{mg} \mathrm{kg}^{-1}$ $\left(-7.1 \% ; \mathrm{CL}_{95 \%}=-12.9\right.$ to $\left.-0.9 \% ; p<0.05\right)$ do indicate that, in some cases, Rbizobium MPN had still not fully recovered by 2005 (Fig. 5c).

\section{Cadmium}

The overall effect of the Cd sludge treatment for the 1999 and 2001 sampling events was approximately $-4 \%$ in each case (Fig. 6a), neither of which was statistically significant. Nevertheless, the overall effect of the Cd sludge treatment was negative for the duration of the LTSE (Fig. 6a and 6b). Significant effects were observed in $2003\left(-10.9 \% \mathrm{CL}_{95 \%}=-14.5\right.$ to -7.1 ; $p<0.001)$ and $2005\left(-7.9 \% ; \mathrm{CL}_{95 \%}=-11.0\right.$ to $\left.-4.7 ; p<0.001\right)$, although in both cases the $95 \%$ confidence limits overlapped with those for 1999 and 2001. Little change was seen in the cumulative effect with time (Fig. 6b); however, excluding data where the total Cd exceeded the UK limit caused an increase in the overall effect for 2005 , from $-4.6 \%\left(\mathrm{CL}_{95 \%}=-7.2\right.$ to $-1.8 \%$; $p<0.01)$ to $-6.0 \%\left(\mathrm{CL}_{95 \%}=-9.4\right.$ to $\left.-2.5 \% ; p<0.01\right)$. However, below $1.5 \mathrm{mg} \mathrm{Cd} \mathrm{kg}{ }^{-1}$, little change in effect was seen with time (Fig. 6c). A positive effect of $6.0 \%\left(\mathrm{CL}_{95 \%}=-12.7\right.$ to $28.7 \%$; $p=0.557)$ was seen in 2001, although in this case, two of the $k=3$ studies are from the silty clay loam soils in which the effect of the $\mathrm{Cd}$ sludge treatment was least (Fig. 2c).

\section{Discussion}

A statistical review of the LTSE experimental data has previously been commissioned by the UK Department for Environment, Food and Rural Affairs. Repeated measure ANOVA and multiple regression were used to combine experimental data for each of the LTSE field sites (with the exception of Shirburn) into a single analysis (Department for Environment, Food and Rural Affairs, 2008). In this case, a significant experimental confound was identified that affected data interpretation. The sludge used to produce the $\mathrm{Zn}$ experimental treatment also contained significantly higher concentrations of $\mathrm{Cu}$ and $\mathrm{Cd}$ than the uncontaminated control, whereas the Cd sludge treatment also contained significantly higher concentrations of $\mathrm{Zn}$ (Table 4; Department for Environment, Food and Rural Affairs, 2008).

Given that the $\mathrm{Cu}$ sludge treatment was least affected by confounding metal contamination, the effect of $\mathrm{Cu}$ on Rhizobium MPN was determined first and then used to "adjust" the data by adding $-m \times \ln ([\mathrm{Cu}])$ to the Rhizobium MPN observed in soils receiving the $\mathrm{Zn}$ and $\mathrm{Cd}$ sludge treatments, where $m$ is the slope of the regression between $\ln ([\mathrm{Cu}])$ and Rhizobium MPN and $[\mathrm{Cu}]$ is the total concentration of $\mathrm{Cu}$ in a given plot (Department for Environment, Food and Rural Affairs, 2008). For the $\mathrm{Cu}$ sludge treatment, the Department for Environment, Food and Rural Affairs (2008) observed a $-13 \%$ decrease in Rhizobium MPN as total $\mathrm{Cu}$ concentrations increased from background levels to the UK statutory limit. This is in agreement with the results shown in Fig. 3b, where mean total Cu ranges from $<170$ to $200 \mathrm{mg} \mathrm{kg}^{-1}$; however, the overall effect for the soils where total $\mathrm{Cu}$ was closest to the statutory limit were less than half this value. As part of investigations into the effects of $\mathrm{Zn}$ and $\mathrm{Cu}$ on Rhizobium leguminosarum biovar trifolii (sampled at an additional long-term sludge experiment at the ADAS Research Centre in Gleadthorpe, Nottinghamshire, UK), Chaudri et al. (2000) reported a lowest observed effect concentration (LOEC) for $\mathrm{Cu}$ (i.e., the concentration at which the observed difference between Rhizobium MPN in contaminated and uncontaminated soil is $>1 \log _{10}$ unit) of $\geq 250$ $\mathrm{mg} \mathrm{kg}^{-1}$. Soils received an application $\left(100 \mathrm{tha}^{-1}\right)$ of contaminated sludge in 1982, followed by an additional application in 1986, giving an overall metal loading of $2077 \mathrm{~kg} \mathrm{Cu} \mathrm{ha}^{-1}$, and were sampled $10 \mathrm{yr}$ after the final sludge application was made. In this case, Rhizobium MPN had decreased to approximately $3.5 \log _{10}$ cells $\mathrm{g}^{-1}$ soil in soils where total $\mathrm{Cu}$ remained at $254 \mathrm{mg} \mathrm{kg}^{-1}$, in comparison to soil receiving uncontaminated sludge where the Rhizobium MPN was approximately $4.5 \log _{10}$ cells $\mathrm{g}^{-1}$ soil. Calculating the $\log$ response ratio for this difference $(\ln (R)=\ln (3.5)-\ln (4.5)$; Eq. [2]) corresponds to a difference of approximately $-22 \%$ (Eq. [15]), which is twice as much as any of the effect sizes observed for the $\mathrm{Cu}$ sludge treatment during the current investigation. However, during the course of the LTSE, total $\mathrm{Cu}$ was found to be $>250 \mathrm{mg}$ $\mathrm{kg}^{-1}$ in only four cases: at Hartwood and Shirburn in 1999 (DoseResponse Levels 4-5) and at Auchincruive in 2003 (Level 4). The effect at Hartwood $(-19.3 \%)$ agreed more with previous findings but occurred at a lower concentration of total $\mathrm{Cu}\left(206.5 \mathrm{mg} \mathrm{kg}^{-1}\right)$.

Chaudri et al. (2008) also reviewed the findings of the LTSE, reporting percentage reductions in Rhizobium MPN, determined 


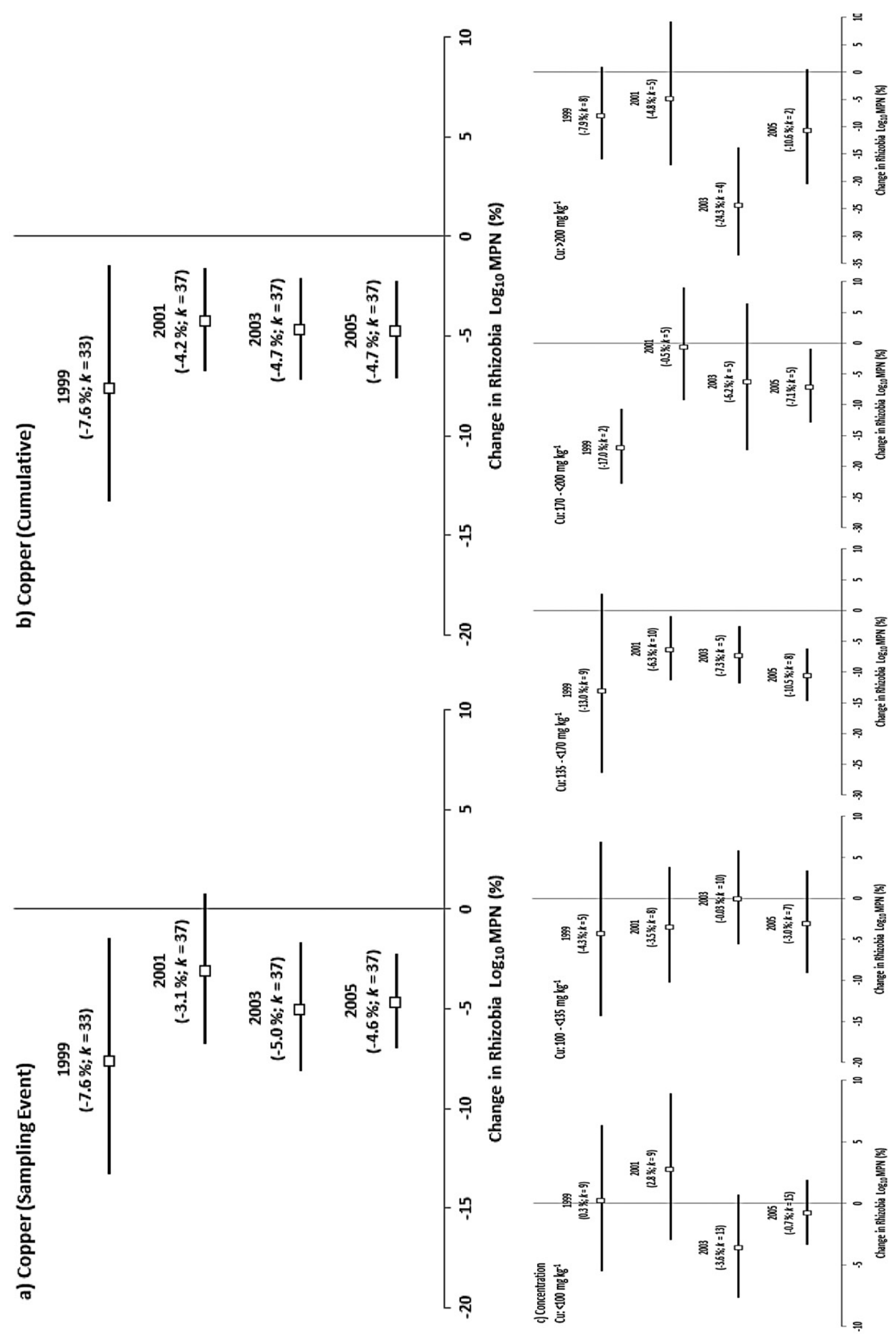

Fig. 5. Forest plots showing the change in effect of the Cu sludge treatment on Rhizobium most probable number of cells (MPN) with time: (a) after each sampling event, (b) cumulative effect with time, and (c) the change in effect with time and increasing concentrations of total $\mathrm{Cu}$. Each point ( $\square$ ) represents the summary effect size for specified sampling events, with the exception of the cumulative effect, which represents the mean effect over consecutive years. The number of primary studies $(k)$ used to calculate each effect size is indicated. Horizontal lines represent $95 \%$ confidence limits. Effects are not statistically significant if $95 \%$ confidence limit crosses the zero line. 

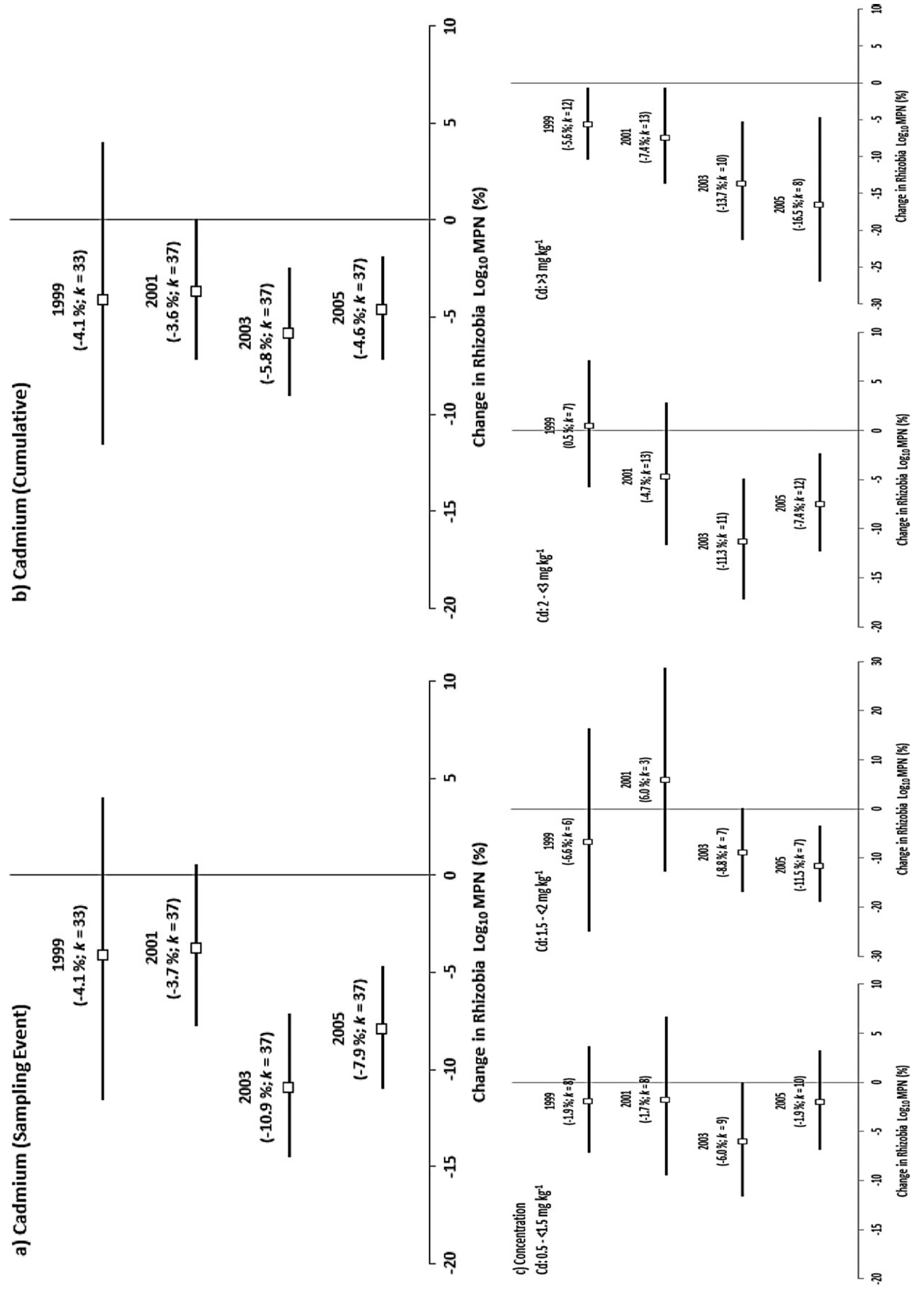

Fig. 6. Forest plots showing the change in effect of the Cd sludge treatment on Rhizobium most probable number of cells (MPN) with time: (a) after each sampling event, (b) cumulative effect with time, and (c) the change in effect with time and increasing concentrations of total $\mathrm{Cd}$. Each point $(\square)$ represents the summary effect size for specified sampling events, with the exception of the cumulative effect, which represents the mean effect over consecutive years. The number of primary studies $(k)$ used to calculate each effect size is indicated. Horizontal lines represent $95 \%$ confidence limits. Effects are not statistically significant if $95 \%$ confidence limit crosses the zero line. 
by multiple regression, for soils where the total concentrations of $\mathrm{Zn}, \mathrm{Cu}$, and $\mathrm{Cd}$ were at the respective UK statutory limits. In soils receiving the $\mathrm{Cu}$ sludge treatment, reductions in Rhizobium MPN ranged from $-5 \%$ (Hartwood and Rosemaund in 1999; Bridgets in 2005) to $-31 \%$ (Gleadthorpe in 1999), although no consistent trends were seen with time. Combining the data using meta-analysis also revealed no significant change in Rhizobium MPN with time. Several significant relationships between Rhizobium MPN and total $\mathrm{Cu}$ have been found previously, particularly in 1999 (Table 6), although in the present study significant effects were not observed until total $\mathrm{Cu}$ increased above $135 \mathrm{mg} \mathrm{kg}^{-1}$. Hence with regard to protecting Rbizobium populations, the current UK statutory limit for $\mathrm{Cu}$ appears to be sufficient.

Adjusting for the concentration of $\mathrm{Cu}$ in soils receiving the $\mathrm{Zn}$ sludge treatment, the Department for Environment, Food and Rural Affairs (2008) observed a decrease in Rbizobium MPN of $-24 \%$ as total $\mathrm{Zn}$ increased from background concentrations to the UK statutory limit, in agreement with the overall effect determined for the $\mathrm{Zn}$ sludge treatment. Taking the confounding $\mathrm{Cu}$ contamination into account, no significant interaction was found between the effects of $\mathrm{Zn}$ and $\mathrm{Cu}$, suggesting that there was no additive effect between the two metals in soils receiving the Zn sludge treatment (Department for Environment, Food and Rural Affairs, 2008). Similarly, Chaudri et al. (2000) did not observe an additive effect of $\mathrm{Zn}$ and $\mathrm{Cu}$ in soils receiving a combined sludge treatment contaminated with both $\mathrm{Zn}$ and $\mathrm{Cu}$. In this case, significant reductions in Rhizobium MPN $\left(>1 \log _{10}\right.$ unit), comparable to soils with high concentrations of total $\mathrm{Zn}$ (291-441 $\mathrm{mg} \mathrm{kg}^{-1}$ ), were seen in soils where $\mathrm{Zn}$ and $\mathrm{Cu}$ were present at concentrations of 230 to 328 and 159 to $223 \mathrm{mg} \mathrm{kg}^{-1}$, respectively. However, the observed effect on Rhizobium MPN was greatly reduced in soils receiving a $\mathrm{Cu}$ sludge treatment where only $\mathrm{Cu}$ was present at concentrations of 160 to $254 \mathrm{mg}$ $\mathrm{kg}^{-1}$ (Chaudri et al., 2000). Therefore, in the current situation, if it is assumed that $\mathrm{Zn}$ and $\mathrm{Cu}$ do not have an additive effect, then clearly $\mathrm{Zn}$ is having a significant effect on Rhizobium MPN at concentrations below both the UK statutory and advisory limits.

The temporal change in the effect of the $\mathrm{Zn}$ sludge treatment was also discussed by Chaudri et al. (2008). Rhizobium MPN were $\geq 1 \log _{10}$ unit lower in soils receiving the $\mathrm{Zn}$ sludge treatment at Dose-Response Level 3 at eight of the nine LTSE field sites in 2005, with the exception of the Shirburn site, where no significant decreases were observed (Table 6). With the exception of 2005, the mean percentage reductions $(1999=-24.5 \%[n=2] ; 2001$ $=33.7 \%[n=6] ; 2003=37.2 \%[n=6] ; 2005=44.3 \%[n=8])$ calculated by Chaudri et al. (2008), where total $\mathrm{Zn}$ was set equal to $300 \mathrm{mg} \mathrm{kg}^{-1}$, were in agreement with the overall effects calculated here, for each sampling event, where total $\mathrm{Zn}$ ranged from 300 to $<350 \mathrm{mg} \mathrm{kg}^{-1}$ (Fig. 4c). The range of calculated percentage decreases also increased with time, corresponding to the observed increases in confidence limits, indicating that the change in the effect of the $\mathrm{Zn}$ sludge treatment was not uniform at all sites. Chaudri et al. (2008) concluded that no clear threshold for the effect of $\mathrm{Zn}$ could be determined and that the observed decrease in Rbizobium is mostly proportional to the total concentration of $\mathrm{Zn}$ present in the soil. The results presented here support this conclusion, as the effect of the $\mathrm{Zn}$ sludge treatment was negative at all levels of the dose-response curve. In addition, Chaudri et al.
(2000) and Broos et al. (2005) reported LOEC values for $\mathrm{Zn}$ in sludge-amended soils of 90 and $233 \mathrm{mg} \mathrm{kg}^{-1}$, respectively, which are also consistent with the results presented here. Evidently the current UK statutory limit is not sufficient to prevent a decline in Rhizobium populations in sludge-amended soils. However, the results presented here indicate that the proposed advisory limit may also not be sufficient. Hence, it would be more practical to adopt a statutory limit for $\mathrm{Zn}$ based on a "critical" percentage reduction of Rhizobium, suggested by Chaudri et al. (2008), below which $\mathrm{N}_{2}$ fixation is known to become impaired.

The highest concentration of $\mathrm{Cd}$ measured during the LTSE was $4.7 \mathrm{mg} \mathrm{kg}^{-1}$ at the Hartwood field site in 2001, where the soil received the Cd sludge treatment at Dose-Response Level 4 (Supplemental material). Hence all the concentrations of $\mathrm{Cd}$ considered here fall within the range of 0.6 to $17.6 \mathrm{mg} \mathrm{kg}^{-1}$, across which Broos et al. (2005) saw no effect of $\mathrm{Cd}$ on Rhizobium in sludge-amended soils; nor was any significant effect observed in soils spiked with $\mathrm{Cd}$ salts, with total $\mathrm{Cd}$ concentrations of 31.5 and $35.4 \mathrm{mg} \mathrm{kg}^{-1}$. Similarly, Renella et al. (2007) observed no effect of $\mathrm{Cd}$ in a grassland soil amended with spiked sewage sludge where total Cd was four times $\left(12 \mathrm{mg} \mathrm{kg}^{-1}\right)$ the UK limit. A significant $(p<0.05)$ decrease in Rhizobium was observed in an arable soil receiving the same sludge treatment; however, the reduction was lower than in a soil amended with $\mathrm{Zn}$-spiked sludge at the UK limit. Therefore if $\mathrm{Cd}$ does not appear to have an effect on Rhizobium at concentrations below the UK limit, then it is possible that the effect of the $\mathrm{Cd}$ sludge treatment observed during the LTSE is due to the confounding $\mathrm{Zn}$ contamination. Chaudri et al. (2008) observed no consistent trends with time in LTSE soils receiving the $\mathrm{Cd}$ sludge treatment, although the number of significant linear relationships between Rhizobium MPN and total Cd increased from $n=0$ in 1999 to $n=4$ in 2005, suggesting an increase in the effect with time (Table 6). However, the relationships seen at Gleadthorpe (in 2001), Rosemaund (in 2003), Shirburn (in 2003), and Pwllpeiran (in 2005) were also significant when regressed against total $\mathrm{Zn}$ (Chaudri et al., 2008). In addition, total $\mathrm{Zn}$ and total $\mathrm{Cd}$ were found to be significantly collinear at a number of sites (e.g., $R^{2}=0.61-0.98$ at Gleadthorpe, Hartwood, and Pwllpeiran in 2005). Therefore, it was not possible to fully determine which metal was having an effect, although it was presumed that the observed decreases in Rhizobium MPN were due to the presence of $\mathrm{Zn}$ (Chaudri et al., 2008).

The apparently anomalous change in the cumulative effect that was observed when the data for soils with a concentration of $\mathrm{Cd}$ exceeding the UK limit were removed from the meta-analysis could also be explained by the presence of $\mathrm{Zn}$ because little change in the range of mean $\mathrm{Zn}$ concentrations was observed (85.0-213.0 to $85.0-173.4 \mathrm{mg} \mathrm{kg}^{-1}$ ) when the data were excluded. A comparable effect was also observed for soils where the mean total Cd ranged from 1.5 to $<2 \mathrm{mg} \mathrm{kg}^{-1}$, in which the mean total $\mathrm{Zn}$ also ranged from 100 to $173.4 \mathrm{mg} \mathrm{kg}^{-1}$ (Fig. 3c). Hence, during the course of the LTSE, Zn has been present in soils receiving the $\mathrm{Cd}$ sludge treatment at concentrations capable of producing an observable effect (Fig. 3a). Adjusting for the concentration of $\mathrm{Cu}$ in the $\mathrm{Cd}$ sludge treatment, the Department for Environment, Food and Rural Affairs (2008) observed a $15 \%$ decrease in Rhizobium MPN as concentrations of total $\mathrm{Cd}$ increased from background levels to the UK statutory limit. This is in agreement with the overall effect determined in 2005 
for soils where total Cd was $>3 \mathrm{mg} \mathrm{kg}^{-1}$, ranging from 3.1 to 4.2 $\mathrm{mg} \mathrm{kg}^{-1}$ (Supplemental Table S1). However, in this case total $\mathrm{Zn}$ also ranged from 113.3 to $192.1 \mathrm{mg} \mathrm{kg}^{-1}$ (with one outlier above $200 \mathrm{mg} \mathrm{kg}^{-1}$ at Shirburn; Supplemental Table S1). Hence these soils, predominantly receiving the $\mathrm{Cd}$ sludge treatment at Dose-Response Level 4, are largely comparable to soils receiving the $\mathrm{Zn}$ sludge treatment at Dose-Response Level 1. This level of $\mathrm{Zn}$ concentration is also capable of producing a $15 \%$ decrease in Rbizobium MPN. Below the UK statutory limits, the overall cumulative effect size observed for the $\mathrm{Zn}$ sludge treatment was approximately 3.5 times greater than that of the $\mathrm{Cd}$ treatment and approximately 20 times greater than that of the $\mathrm{Cu}$ sludge treatment (see above). In agreement with both Broos et al. (2005) and Renella et al. (2007), this would suggest that the order of metal toxicity is $\mathrm{Zn}>\mathrm{Cd}>\mathrm{Cu}$. Given that $\mathrm{Cd}$ does not appear to have a significant effect on Rhizobium below $4 \mathrm{mg} \mathrm{kg}^{-1}$, then the observed decreases in Rhizobium MPN in soils receiving the $\mathrm{Cd}$ sludge treatment could be caused by $\mathrm{Zn}$. If this is so, then it gives further indication that an advisory limit of $200 \mathrm{mg}$ $\mathrm{Zn} \mathrm{kg}{ }^{-1}$ may not be sufficient. Of the three heavy metals applied during the LTSE, clearly $\mathrm{Zn}$ has had the greatest impact on the Rhizobium populations of the receiving soils.

The approach to mitigating heavy metal accumulation in sludge-amended soils varies among different countries and largely depends on soil usage priorities and the extent of environmental impact tolerated (McGrath et al., 1994). The USEPA has performed an environmental risk assessment and analysis of exposure pathways whereby metal toxicity may occur in plants, animals, and humans. A number of potential exposure routes were considered by the USEPA, resulting in some of the highest metal loadings permitted with regard to the application of sewage sludge to agricultural land (Table 8); notably the only consideration of soil biota was the potential bioaccumulation of heavy metals in earthworms (McBride, 1995; McGrath et al., 1994). The majority of EU member states do permit a certain degree of metal accumulation, with the statutory limits set by the UK Sludge (Use
In Agriculture) Regulations being among if not the highest in Europe (Table 8). In this case, the approach is to adopt statutory limits below the minimum concentrations of heavy metals known to have an adverse effect on soil microorganisms (McGrath et al., 1994). The most cautious method is the "metal-balance" approach adopted by countries such as Sweden, Denmark, and the Netherlands. This approach recognizes the extreme persistence of heavy metals and tries to match the rate of sludge application with that of loss processes to prevent a net accumulation of heavy metals. As a result of this, the statutory limits significantly restrict the recycling of sewage sludge to agricultural land in those countries (Table 8). Although there is little evidence to support the need for such conservative limits, Witter (1996) suggested that this approach provides more of an incentive to reduce metal emissions to wastewater, thus improving the overall quality of sewage sludge. This is clearly a desirable situation and an obvious solution to the problem of heavy metals accumulating in agricultural land due to the application of sewage sludge. The contaminated sludge treatments applied during the LTSE are clearly exceptional cases and, outside of the UK, their use in agriculture would not be permitted within any of the EU countries mentioned in Table 8 , although application of the $\mathrm{Zn}$ sludge treatment would be permitted in the United States.

\section{Conclusions}

The total metal loadings applied during the course of the LTSE represent a case of acute exposure to heavy metal contamination, rather than a chronic accumulation, which may influence both the short-term and long-term response of soil microorganisms. However, the results presented here clearly show a decline in Rhizobium MPN due to the historical application of sewage sludge contaminated with $\mathrm{Zn}$. Results further indicate that sludge-borne $\mathrm{Zn}$ has an observable effect on Rhizobium at concentrations below both the UK statutory limit and the UK advisory limit. Therefore a reduction in the UK statutory limit may be necessary to prevent the loss of Rhizobium from agricultural soils. No consistent trend

Table 8. Maximum permissible concentrations for heavy metals in sewage sludge and sludge-amended soils adopted by EU member states and the United States (adapted from Ministry of Agriculture, Fisheries and Food, 1993b; McGrath et al., 1994; Smith, 1996).

\begin{tabular}{|c|c|c|c|c|c|c|c|c|c|c|c|}
\hline \multirow{2}{*}{ Metal } & \multicolumn{11}{|c|}{ Total metal concentration } \\
\hline & France & Germany & Italy & Spain & the Netherlands & UK† & Denmark & Finland & Norway & Sweden & USA \\
\hline & \multicolumn{11}{|c|}{$\longrightarrow \mathrm{mg} \mathrm{kg}^{-1} \longrightarrow$} \\
\hline & \multicolumn{11}{|c|}{ Sludge } \\
\hline $\mathrm{Cd}$ & 20 & 10 & 20 & 20 & 1.25 & - & 1.2 & 1.5 & 4 & 2 & 5 \\
\hline $\mathrm{Cu}$ & 1000 & 800 & 1000 & 1000 & 75 & - & 1000 & 600 & 1000 & 600 & 4300 \\
\hline $\mathrm{Pb}$ & 800 & 900 & 750 & 750 & 100 & - & 120 & 100 & 100 & 100 & 840 \\
\hline $\mathrm{Hg}$ & 10 & 8 & 10 & 16 & 0.75 & - & 1.2 & 1.0 & 5 & 2.5 & 57 \\
\hline $\mathrm{Ni}$ & 200 & 200 & 300 & 300 & 30 & - & 45 & 100 & 80 & 50 & 420 \\
\hline \multirow[t]{2}{*}{$\mathrm{Zn}$} & 3000 & 2500 & 2500 & 2500 & 300 & - & 4000 & 1500 & 1500 & 800 & 7500 \\
\hline & \multicolumn{11}{|c|}{ Soil\# } \\
\hline $\mathrm{Cd}$ & 2 & 1.5 & 3 & 1 & 0.8 & 3 & 0.5 & 0.5 & 1 & 0.5 & 20 \\
\hline $\mathrm{Cu}$ & 100 & 60 & 100 & 50 & 36 & 135 & 40 & 100 & 50 & 40 & 750 \\
\hline $\mathrm{Pb}$ & 100 & 100 & 100 & 50 & 85 & 300 & 40 & 60 & 50 & 40 & 150 \\
\hline $\mathrm{Hg}$ & 1 & 1 & 1 & 1 & 0.3 & 1 & 0.5 & 0.2 & 1 & 0.5 & 8 \\
\hline $\mathrm{Ni}$ & 50 & 50 & 50 & 30 & 35 & 75 & 15 & 60 & 30 & 15 & 210 \\
\hline $\mathrm{Zn}$ & 300 & 200 & 300 & 150 & 140 & 300 & 100 & 150 & 150 & 100 & 1400 \\
\hline
\end{tabular}

†The UK Sludge (Use in Agriculture) Regulations do not set maximum limits for heavy metals in sewage sludge. Instead, metal loadings (kg ha ${ }^{-1} \mathrm{yr}^{-1}$ ) are to be kept below a specified annual average over a 10-yr period (Table 1).

₹ Concentration in soils with $\mathrm{pH} 6$ to 7 .

Journal of Environmental Quality 
in the effects of $\mathrm{Cu}$ and $\mathrm{Cd}$ were observed in the present study, nor have they been observed previously when considering each of the nine field sites separately. Hence, with regard to protecting Rbizobium, there does not appear to be anything present within the LTSE data set that would give cause for changing the current $\mathrm{UK}$ limit for $\mathrm{Cu}$ or $\mathrm{Cd}$. The implication of this work is that continued evaluation of the long-term impact of sludge-borne heavy metals is necessary to prevent the occurrence of adverse effects that may have previously been overlooked.

\section{Acknowledgments}

This research was funded by the European Union Seventh Framework Programme (FP7-ENV.2010.3.1.1-2 ENV) under Grant Agreement no. 265269. Rothamsted Research receives strategic funding from the UK Biotechnology and Biological Sciences Research Council. Colin D. Campbell is funded by the Scottish Government Rural Affairs and Analytical Services Division (RESAS). Alex Charlton also received part funding from the EPSRC Doctoral Training Account. We would also like to acknowledge Pat Cooper, Bill Crooks, and the team from ADAS for their contribution to background data collection. This paper is in memory of the late Professor Brian Chambers of ADAS, without whose dedication, insight, and drive, the UK Long term Sludge Network on which this paper is based would not have been possible.

\section{References}

Alloway, B.J., and A.P. Jackson. 1991. The behaviour of heavy metals in sewage sludge-amended soils. Sci. Total Environ. 100:151-176. doi:10.1016/0048-9697(91)90377-Q

Berrow, M.L., and J. Webber. 1972. Trace elements in sewage sludges. J. Sci. Food Agric. 23:93-100. doi:10.1002/jsfa.2740230112

Borenstein, M. 2000. The shift from significance testing to effect size estimation. In: A.S. Bellack and M. Hersen, editors, Comprehensive clinical psychology. Vol. 3 . Pergamon Press, Oxford, UK. p. 313-349.

Borenstein, M., L.V. Hedges, J.P.T. Higgins, and H.R. Rothstein. 2009. In troduction to meta-analysis. John Wiley \& Sons Ltd., Chichester, UK. doi: $10.1002 / 9780470743386$

Broos, K., H. Beyens, and E. Smolders. 2005. Survival of rhizobia in soil is sensitive to elevated zinc in the absence of the host plant. Soil Biol. Biochem. 37:573-579. doi:10.1016/j.soilbio.2004.08.018

CEC. 1986. Council Directive EU Sewage Sludge Directive 86/278/EEC of 12th June 1986 on the Protection of the environment and the soil when sewage sludge is used in agriculture. Official Journal of the European Community L181. European Union.

Chaudri, A.M., C.M.G. Allain, V.L. Barbosa-Jefferson, F.A. Nicholson, B.J. Chambers, and S.P. McGrath. 2000. A study of the impacts of $\mathrm{Zn}$ and Cd on two rhizobial species in soils of a long-term field experiment. Plant Soil 221:167-179. doi:10.1023/A:1004735705492

Chaudri, A.M., S.P. McGrath, P. Gibbs, B. Chambers, C. Carlton-Smith, J. Bacon, et al. 2008. Population size of indigenous Rhizobium leguminosarum biovar trifolit in long-term field experiments with sewage sludge cake, metal-amended liquid sludge or metal salts: Effects of zinc, copper and cadmium. Soil Biol. Biochem. 40:1670-1680. doi:10.1016/j.soilbio.2008.01.026

Chaudri, A.M., S.P. McGrath, and K.E. Giller. 1992. Survival of the indigenous population of Rhizobium leguminosarum biovar trifolii in soil spiked with $\mathrm{Cd}, \mathrm{Zn}, \mathrm{Cu}$, and $\mathrm{Ni}$ salts. Soil Biol. Biochem. 24:625-632. doi:10.1016/0038-0717(92)90040-5

Chaudri, A.M., S.P. McGrath, K.E. Giller, E. Rietz, and D.R. Sauerbeck. 1993. Enumeration of indigenous Rhizobium leguminosarum biovar trifolii in soils previously treated with metal contaminated sewage sludge. Soil Biol. Biochem. 25:301-309. doi:10.1016/0038-0717(93)90128-X

Department for Environment, Food and Rural Affairs. 2007. Waste strategy for England 2007. Defra, London. https://www.gov.uk/government/publications/ waste-strategy-for-england-2007 (accessed 3 Feb. 2016).

Department for Environment, Food and Rural Affairs. 2008. Long-term metal experiments: Statistical review of findings to date and definition of future experimental programme. SP0142. Defra, London.

Gendebien, A., C. Carlton-Smith, M. Izzo, and J.E. Hall. 1999. UK sewage sludge survey: National presentation. R\&D Tech. Rep. P165. WRc plc, Swindon, UK.

Gendebien, A., B. Davis, J. Hobson, R. Palfrey, R. Pitchers, P. Rumsby, et al. 2010. Environmental, economic, and social impacts of the use of sewage sludge on land: Final report. Part III: Project interim reports. Milieu Ltd., Brussels. http:// ec.europa.eu/environment/archives/waste/sludge/pdf/part_iii_report.pdf (accessed 13 Feb. 2016).
Gibbs, P.A., B.J. Chambers, A.M. Chaudri, S.P. McGrath, C.H. Carlton-Smith, J.R. Bacon, et al. 2006. Initial results from a long-term, multi-site field study of the effects on soil fertility and microbial activity of sludge cakes containing heavy metals. Soil Use Manage. 22:11-21. doi:10.1111/j.1475-2743.2006.00003.x

Giller, K.E., S.P. McGrath, and P.R. Hirsch. 1989. Absence of nitrogen fixation in clover grown on soil subject to long-term contamination with heavy metals is due to survival of only ineffective Rhizobium. Soil Biol. Biochem. 21:841-848. doi:10.1016/0038-0717(89)90179-X

Giller, K.E., E. Witter, and S.P. McGrath. 1998. Toxicity of heavy metals to microorganisms and microbial processes in agricultural soils: A review. Soil Biol. Biochem. 30:1389-1414. doi:10.1016/S0038-0717(97)00270-8

Giller, K.E., E. Witter, and S.P. McGrath. 1999. Assessing risks of heavy metal toxicity in agricultural soils: Do microbes matter? Hum. Ecol. Risk Assess. 5:683-689. doi:10.1080/10807039.1999.9657732

Giller, K.E., E. Witter, and S.P. McGrath. 2009. Heavy metals and soil microbes. Soil Biol. Biochem. 41:2031-2037. doi:10.1016/j.soilbio.2009.04.026

Hedges, L.V., J. Gurevitch, and P.S. Curtis. 1999. The meta-analysis of response ratios in experimental ecology. Ecology 80:1150-1156. doi:10.1890/0012-9658(1999)080[1150:TMAORR]2.0.CO;2

Hedges, L.V., and I. Olkin. 1980. Vote-counting methods in research synthesis. Psychol. Bull. 88:359-369. doi:10.1037/0033-2909.88.2.359

Hedges, L.V., and T.D. Pigott. 2001. The power of statistical tests in meta-analysis. Psychol. Methods 6:203-217. doi:10.1037/1082-989X.6.3.203

Hedges, L.V., and J.L. Vevea. 1998. Fixed- and random-effects models in meta-analysis. Psychol. Methods 3:486-504. doi:10.1037/1082-989X.3.4.486

McBride, M.B. 1995. Toxic metal accumulation from agricultural use of sludge: Are USEPA regulations protective? J. Environ. Qual. 24:5-18. doi:10.2134/ jeq 1995.00472425002400010002x

McBride, M.B. 2003. Toxic metals in sewage sludge-amended soils: Has promotion of beneficial use discounted the risks? Adv. Environ. Res. 8:5-19. doi:10.1016/ S1093-0191(02)00141-7

McGrath, S.P. 1987. Long-term studies of metal transfers following application of sewage sludge. In: P.J. Coughtry et al, editors, Pollutant transport and fate in ecosystems. Br. Ecol. Soc. Spec. Publ. 6. Blackwell Scientific, Oxford, UK. p. 25-35.

McGrath, S.P., P.C. Brookes, and K.E. Giller. 1988. Effects of potentially toxic metals in soil derived from past applications of sewage sludge on nitrogen fixation by Trifolium repens L. Soil Biol. Biochem. 20:415-424. doi:10.1016/0038-0717(88)90052-1

McGrath, S.P., A.C. Chang, A.L. Page, and E. Witter. 1994. Land application of sewage sludge: Scientific perspectives of heavy metal loading limits in Europe and the United States. Environ. Rev. 2:108-118. doi:10.1139/a94-006

McGrath, S.P., A.M. Chaudri, and K.E. Giller. 1995. Long-term effects of metals in sewage sludge on soils, microorganisms, and plants. J. Ind. Microbiol. 14:94104. doi:10.1007/BF01569890

Ministry of Agriculture, Fisheries and Food. 1993a. Review of the rules for sewage sludge application to agricultural land: Food safety and relevant animal health aspects of potentially toxic elements. Report of the Steering Group on Chemical Aspects of Food Surveillance. PB 1562. MAFF Publ., London.

Ministry of Agriculture, Fisheries and Food. 1993b. Review of the rules for sewage sludge application to agricultural land: Soil fertility aspects of potentially toxic elements. Independent Scientific Committee on Soil Fertility Aspects of Sewage Sludge Use in Agriculture. PB 1561. MAFF Publ., London.

Renella, G., A.M. Chaudri, C.M. Falloon, L. Landi, P. Nannipieri, and P.C. Brookes. 2007. Effects of $\mathrm{Cd}, \mathrm{Zn}$, or both on soil microbial biomass and activity in a clay loam soil. Biol. Fertil. Soils 43:751-758. doi:10.1007/s00374-006-0159-5

Smith, S.R. 1996. Agricultural recycling of sewage sludge and the environment. CAB Int., Wallingford, UK.

Thornton, I., D. Butler, P. Docx, M. Hession, C. Makropoulos, M. McMullen, et al. 2001. Pollutants in urban waste water and sewage sludge. Final Report to Directorate-General Environment. Office Official Publ. Eur. Commun., Luxembourg.

UK Statutory Instrument. 1989. The Sludge (Use in Agriculture) Regulations 1989, no. 1263. http://www.legislation.gov.uk/uksi/1989/1263/made (accessed 13 Feb. 2016).

UK Water Industry Research Limited. 2002. Effects of sewage sludge applications to agricultural soils on soil microbial activity and the implications for agricultural productivity and long-term soil fertility: Phase II. SP0125. UK Water Industry Res. Ltd., London.

UK Water Industry Research Limited. 2007. Effects of sewage sludge applications to agricultural soils on soil microbial activity and the implications for agricultural productivity and long-term soil fertility: Phase III. SP0130. UK Water Industry Res. Ltd., London.

Vincent, J.M. 1970. A manual for the practical study of root-nodule bacteria. Blackwell, Oxford, UK

Water UK. 2010. Recycling of biosolids to agricultural land. Water UK, London.

Witter, E. 1996. Towards zero accumulation of heavy metals in soils. Fert. Res. 43:225-233. doi: 10.1007/BF00747706

Woomer, P., J. Bennet, and R. Yost. 1990. Overcoming the inflexibility of the mostprobable number procedures. Agron. J. 82:349-353. doi:10.2134/agronj1990. $00021962008200020035 x$ 